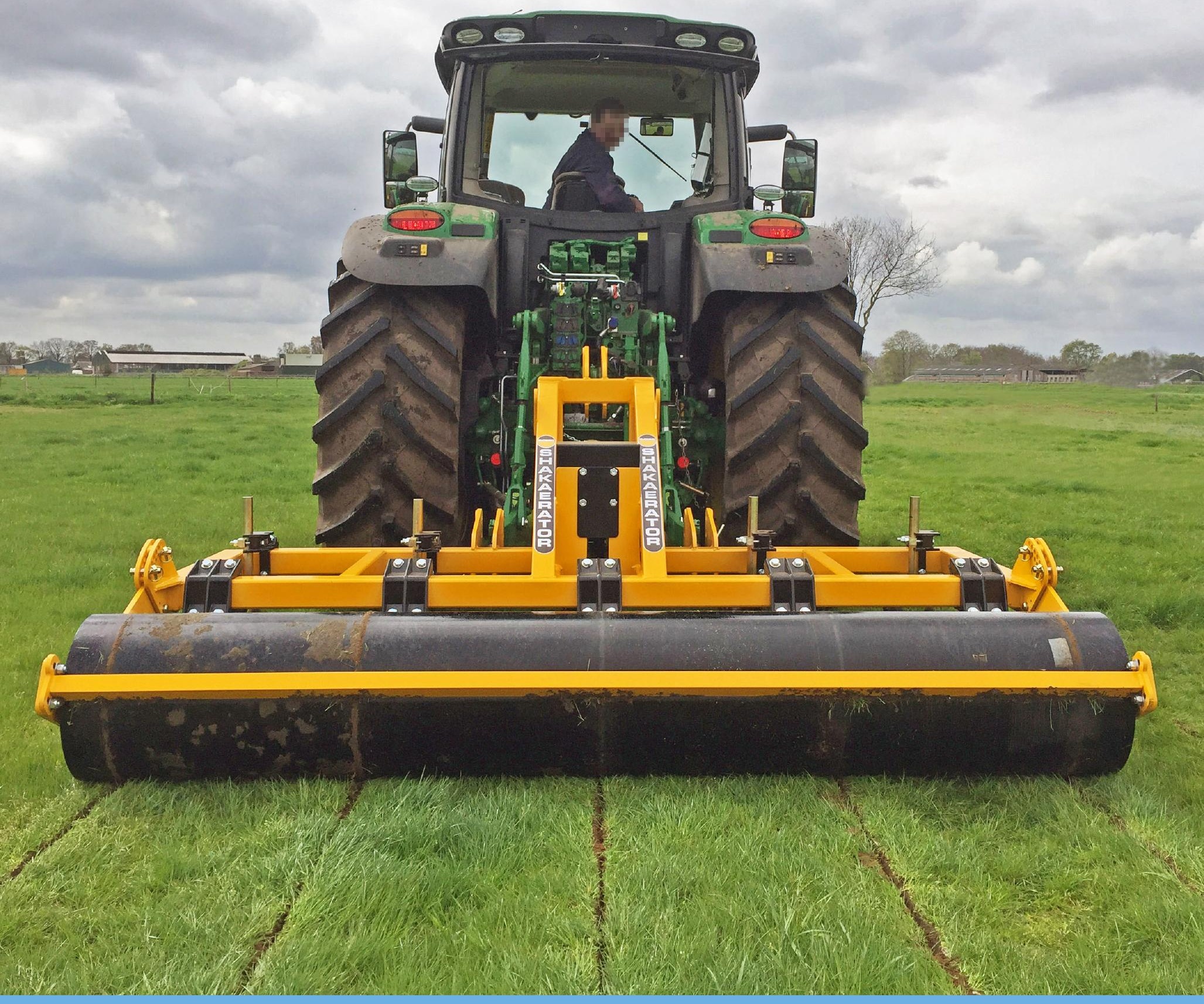

Woelen van verdicht grasland op een zavelgrond en een zware kleigrond: effecten op bodemstructuur, beworteling en productiviteit

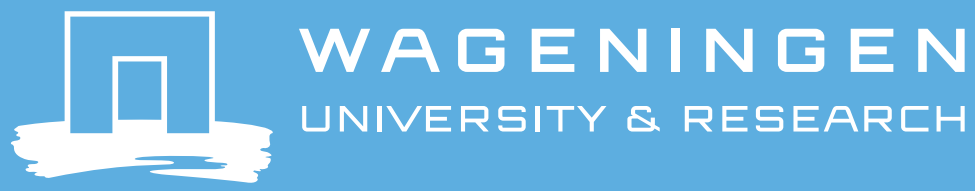




\section{Woelen van verdicht grasland op een zavelgrond en een zware kleigrond: effecten op bodemstructuur, beworteling en productiviteit}

Herman de Boer ${ }^{1)}$

Joachim Deru ${ }^{2)}$

Nick van Eekeren ${ }^{2)}$

1 Wageningen Livestock Research

2 Louis Bolk Instituut

Dit onderzoek is uitgevoerd door Wageningen Livestock Research en het Louis Bolk Instituut, en gefinancierd door ZuiveINL, het Samenwerkingsverband Noord-Nederland (SNN) en het PPS 'Ruwvoerproductie en Bodemmanagement'

Wageningen Livestock Research

Wageningen, september 2018 
De Boer, Herman, Deru, Joachim, van Eekeren, Nick, 2018. Woelen van verdicht grasland op een zavelgrond en een zware kleigrond: effecten op bodemstructuur, beworteling en productiviteit. Wageningen Livestock Research, Rapport 1124

Dit rapport is gratis te downloaden op https://doi.org/10.18174/460212of op www.wur.nl/livestock-research (onder Wageningen Livestock Research publicaties).

(C) 2018 Wageningen Livestock Research

Postbus 338, 6700 AH Wageningen, T 03174839 53, E info.livestockresearch@wur.nl, www.wur.nl/livestock-research. Wageningen Livestock Research is onderdeel van Wageningen University \& Research.

Wageningen Livestock Research aanvaardt geen aansprakelijkheid voor eventuele schade voortvloeiend uit het gebruik van de resultaten van dit onderzoek of de toepassing van de adviezen.

Alle rechten voorbehouden. Niets uit deze uitgave mag worden vermenigvuldigd en/of openbaar gemaakt worden door middel van druk, fotokopie, microfilm of op welke wijze dan ook zonder voorafgaande toestemming van de uitgever of auteur.

Wageningen Livestock Research is NEN-EN-ISO 9001:2015 gecertificeerd.

Op al onze onderzoeksopdrachten zijn de Algemene Voorwaarden van de Animal Sciences Group van toepassing. Deze zijn gedeponeerd bij de Arrondissementsrechtbank Zwolle.

Wageningen Livestock Research Rapport 1124 


\section{Inhoud}

$\begin{array}{ll}\text { Samenvatting } & 5\end{array}$

$\begin{array}{lll}1 & \text { Inleiding } & 7\end{array}$

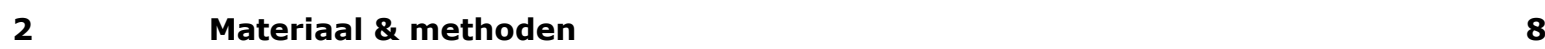

2.1 Proefveldbeschrijving $\quad 8$

2.2 Proefopzet $\quad 8$

2.3 Bemesting 9

2.4 Waarnemingen 9

2.4.1 Bodem 9

2.4.2 Gewas 11

2.5 Statistische analyse $\quad 11$

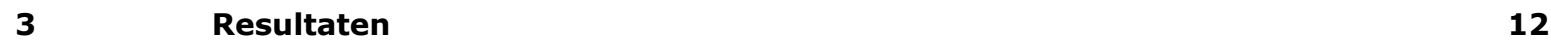

3.1 Bodem 12

3.1.1 Indringingsweerstand 12

3.1.2 Wortelmassa 13

3.1.3 Bodemstructuur, worteldichtheid en wormgangen $\quad 13$

3.1.4 Waterdrainagesnelheid 14

3.1.5 Bulkdichtheid en bodemvruchtbaarheid 15

3.2 Gras 16

3.2.1 Opbrengst 16

$\begin{array}{ll}3.2 .2 \text { Stikstofopname } & 17\end{array}$

$\begin{array}{ll}3.2 .3 \text { Botanische samenstelling } & 17\end{array}$

4

$\begin{array}{lr}\text { Discussie } & 19\end{array}$

4.1 Zavelgrond $\quad 19$

4.2 Zware kleigrond $\quad 21$

$\begin{array}{ll}\text { Conclusies } & 23\end{array}$

Dankwoord $\quad 24$

$\begin{array}{ll}\text { Literatuur } & 25\end{array}$ 


\section{Samenvatting}

Bodemverdichting kan de opbrengst van blijvend grasland verminderen door negatieve effecten op de beworteling. Bodemverdichting in de bouwvoor $(0-30 \mathrm{~cm})$ kan opgeheven worden door het grasland te ploegen en opnieuw in te zaaien. Deze methode is ingrijpend en heeft belangrijke nadelen. Een minder ingrijpende maatregel is woelen. Woelen van blijvend grasland wordt in Nederland nog weinig toegepast en is onder Nederlandse omstandigheden nog weinig onderzocht. In eerder onderzoek, op een perceel zandgrond, waren de positieve effecten van woelen beperkt, waarschijnlijk vanwege een beperkte verdichting. Om de maximale effecten van een woelbehandeling te kunnen meten, zal er een zware verdichting in de bouwvoor aanwezig moeten zijn. In het eerdere onderzoek werd een aantal metingen tijdens een relatief beperkte periode uitgevoerd, en niet langer dan een groeiseizoen. Het is echter wenselijk om deze metingen voor een langere periode uit te voeren, omdat veranderingen pas na langere tijd zichtbaar kunnen worden. Naast zandgrond zijn in Nederland ook klei- en zavelgrond belangrijke minerale grondsoorten, en bij het beoordelen van de effectiviteit van woelen dienen ook de effecten op deze grondsoorten bestudeerd te worden. Daarom werd een tweede veldonderzoek naar de effecten van woelen van blijvend grasland uitgevoerd, dit keer op een perceel verdichte zavelgrond en op een perceel verdichte zware kleigrond. De zavelgrond was zeer sterk verdicht, wat het mogelijk maakte om maximale effecten van woelen op deze grondsoort vast te stellen. In het nieuwe onderzoek werden de effecten van in het najaar woelen gemeten tijdens ruim twee groeiseizoenen. Gemeten werden de effecten op indringingsweerstand van de bodem, bodemstructuur, worteldichtheid, wormgangen, wortelmassa (alleen zavelgrond), snelheid van waterdrainage in het voorjaar (alleen zavelgrond), bulkdichtheid en bodemvruchtbaarheid, grasopbrengst, stikstof(N)opname, en botanische samenstelling. De resultaten laten zien dat woelen van het perceel sterk verdichte zavelgrond over de hele proefperiode (2,5 jaar) een aanhoudende duidelijke verbetering gaf van de bodemstructuur, de beworteling en wormactiviteit. Op het (minder verdichte) perceel zware kleigrond waren de effecten beperkter en korter van duur. Op de zavelgrond liep de waterdrainage op de gewoelde veldjes 10 dagen voor op de controleveldjes. De verbeteringen in bodemstructuur, beworteling en waterdrainage leidden echter niet tot een structureel hogere grasopbrengst en $\mathrm{N}$ opname door het groeiseizoen heen. Op de zavelgrond was de grasopbrengst door woelen hoger in de eerste snede van alle drie groeiseizoenen, maar verschilde deze niet in de volgende sneden. Over de hele proefperiode was de opbrengst $4 \%$ hoger. Op de zware kleigrond was de grasopbrengst alleen hoger in de eerste snede van het eerste groeiseizoen, en in de sneden daarna regelmatig lager. Over de hele proefperiode was de opbrengst 6\% lager. Op de zavelgrond was de $\mathrm{N}$-opname in de eerste snede van alle drie groeiseizoenen hoger door woelen (13-22\%). In het eerste groeiseizoen na woelen was ook de $\mathrm{N}$-opname van de derde en vijfde snede, en van het hele seizoen, hoger. Over de hele proefperiode was de $\mathrm{N}$-opname $8 \%$ hoger. Op de zware kleigrond was de $\mathrm{N}$-opname alleen in de eerste snede na woelen hoger, en daarna regelmatig lager. Over de hele proefperiode was de $\mathrm{N}$ opname $4 \%$ lager. Woelen gaf op beide bodemtypen aan het einde van de proefperiode een lagere bodemvruchtbaarheid, gemeten aan de gehalten OS, C-totaal en N-totaal in de bouwvoor $(0-30 \mathrm{~cm})$. Op de zavel- en zware kleigrond was de $\mathrm{N}$-voorraad van de gewoelde veldjes toen respectievelijk $1 \%$ (66 $\mathrm{N} \mathrm{ha}^{-1}$ ) en $4 \%$ (618 $\mathrm{kg} \mathrm{N} \mathrm{ha}^{-1}$ ) lager vergeleken met de controleveldjes. Woelen gaf verder een (geringe) verslechtering van de graszodekwaliteit, door een licht lagere zodebedekking (beide locaties), met daarin een lager relatief aandeel van L. perenne (zware klei) en een hoger relatief aandeel van $P$. trivialis (zware klei). De zware kleigrond bleek in staat om de aanwezige verdichting op natuurlijke wijze op te heffen. Woelen had een averechts effect, waardoor de controleveldjes in betere conditie waren dan de gewoelde veldjes. Wanneer de gemeten kosten en opbrengsten van woelen op directe financiële waarde worden gezet, resteert over de 2,5 jaar durende proefperiode een nettowinst van $€ 209 \mathrm{ha}^{-1}$ op de zavelgrond en een nettoverlies van $€ 1121 \mathrm{ha}^{-1}$ op de zware kleigrond. Woelen was daarmee financieel interessant op de zavelgrond en sterk af te raden op de zware kleigrond. Bij de beslissing om verdicht grasland wel of niet te woelen is dus maatwerk nodig, waarbij de mate van verdichting en de natuurlijke herstelcapaciteit van de grond een belangrijke rol spelen. 


\section{$1 \quad$ Inleiding}

Bodemverdichting kan de opbrengst van blijvend grasland verminderen door negatieve effecten op de beworteling en de activiteit van het bodemleven. De beworteling kan verslechteren door de aanwezigheid van minder zuurstof in de bodem en meer fysieke weerstand. Het bodemleven wordt zowel negatief beïnvloed door minder zuurstof in de bodem als door een afname van de beschikbaarheid van voeding via de wortels. Bij een slechtere beworteling (ondieper en/of minder intensief) kunnen nutriënten door het gras minder goed uit de bodem opgenomen en benut worden. Een lagere activiteit van het bodemleven kan leiden tot een verdere verslechtering van de bodemstructuur en daarmee een versterkend negatief effect hebben op de wortelgroei en het vrijkomen van nutriënten. Door een afname van het doorwortelde bodemvolume kan ook de droogtegevoeligheid van het grasland toenemen. De kans op deze negatieve effecten maken het belangrijk om bodemverdichting te voorkomen en bij aanwezigheid op te heffen.

Bodemverdichting in de bouwvoor $(0-30 \mathrm{~cm})$ kan opgeheven worden door het grasland te ploegen en opnieuw in te zaaien. Deze methode is ingrijpend en heeft belangrijke nadelen, zoals relatief hoge kosten, verlies van organische stof, verlies van stikstof en andere nutriënten en verlies van bodembiodiversiteit. Een minder ingrijpende maatregel is het woelen/losmaken van grasland. Hierbij wordt met een graslandwoeler de bodem vanaf bouwvoordiepte opgetild en weer neergelaten, waarbij de graszode intact blijft. Grasland woelen kan daardoor mogelijk toegepast worden als een onderhoudsmaatregel voor blijvend grasland, met als doel de levensduur te verlengen. Het woelen van blijvend grasland wordt in Nederland in de praktijk nog weinig toegepast en is maar beperkt onderzocht.

Woelen van de bouwvoor van verdicht grasland kan de bodemstructuur en beworteling voor langere tijd verbeteren. Deze verbeteringen vertalen zich echter lang niet altijd in een hogere grasopbrengst en een betere benutting van meststoffen. In eerder onderzoek op een zandgrond gaf woelen alleen een tijdelijke verhoging van de grasopbrengst en stikstof(N)-opname, als gevolg van een tijdelijk hogere mineralisatie van bodemorganische N (De Boer et al. 2018). In dat onderzoek werd een licht hogere $\mathrm{N}$-opname in het eerste groeiseizoen na woelen (in het najaar) volledig gecompenseerd door een licht lagere $\mathrm{N}$-opname in het tweede groeiseizoen. Geconstateerd werd dat de beperkte effecten van woelen in dit onderzoek mogelijk het gevolg waren van een beperkte verdichting. Om de maximale effecten van een woelbehandeling te kunnen meten, zal er een zware verdichting in de bouwvoor aanwezig moeten zijn. In het eerdere onderzoek werd een aantal metingen tijdens een relatief beperkte periode uitgevoerd; de indringingsweerstand en wortelmassa werden bijvoorbeeld niet langer gemeten dan tot 12 maanden na het woelen. Het is echter wenselijk om deze metingen voor een langere periode uit te voeren, omdat veranderingen in bijvoorbeeld de beworteling pas na langere tijd zichtbaar kunnen worden. In onderzoek van Harrison et al. (1994) werden veranderingen in wortellengte pas zichtbaar 13 maanden na het losmaken van de ondergrond. Naast zandgrond zijn in Nederland ook klei- en zavelgrond belangrijke minerale grondsoorten voor de grasteelt. Bij het beoordelen van de effectiviteit van woelen is het daarom nodig om ook de effecten op deze grondsoorten te bestuderen.

Om aandacht te besteden aan bovenstaande punten werd een tweede veldonderzoek naar de effecten van woelen van blijvend grasland uitgevoerd, dit keer op zowel een perceel verdichte zavelgrond als op een perceel verdichte zware kleigrond. De zavelgrond was bij aanvang van het onderzoek zeer sterk verdicht, wat het mogelijk maakte om maximale effecten van woelen op deze grondsoort vast te stellen. In het nieuwe onderzoek werden de effecten van in het najaar woelen tijdens ruim twee groeiseizoenen gemeten. Het voorliggende rapport beschrijft de opzet, uitvoering en resultaten van dit nieuwe onderzoek. 


\section{Materiaal \& methoden}

\section{$2.1 \quad$ Proefveldbeschrijving}

Het onderzoek werd uitgevoerd op blijvend grasland op twee bodemtypen: een zavelgrond en een zware zeekleigrond, beide gelegen in het noorden van Nederland, op een onderlinge afstand (hemelsbreed) van $8 \mathrm{~km}$. Het perceel zavelgrond $\left(5^{\circ} 13^{\prime} 48 \mathrm{~N}, 5^{\circ} 42^{\prime} 50 \mathrm{E}\right)$ was gedraineerd op 0,8 m diepte en met een drainafstand van $10 \mathrm{~m}$. Desondanks was dit perceel gevoelig voor wateroverlast, als gevolg van ernstige verdichting in de bovenste $60 \mathrm{~cm}$ van het bodemprofiel (Figuur 1).

Bodemeigenschappen van de laag $0-30 \mathrm{~cm}$ waren (in droge grond): lutum $11 \%$, silt $35 \%$, zand $52 \%$, $\mathrm{pH}-\mathrm{KCl} 6,4$, organische stof $20 \mathrm{~g} \mathrm{~kg}^{-1}$, C-totaal $9 \mathrm{~g} \mathrm{~kg}^{-1}, \mathrm{~N}$-totaal N 1,01 g kg-1, P-Al 0,32 $\mathrm{g} \mathrm{P}_{2} \mathrm{O}_{5} \mathrm{~kg}^{-1}$, $\mathrm{K}-\mathrm{CaCl}_{2}(0,01 \mathrm{M}) 0,061 \mathrm{~g} \mathrm{~kg}^{-1}$ en S-CaCl $2(0,01 \mathrm{M}) 0,010 \mathrm{~g} \mathrm{~kg}^{-1}$. Het zavelperceel had een aanzienlijke capillaire opstijging van grondwater gedurende het groeiseizoen en was daardoor weinig droogtegevoelig. Een visuele beoordeling van de bodemstructuur en beworteling, kort voor de start van het onderzoek, liet zien dat de laag 0-6 cm een goede bodemstructuur had (hoog aandeel kruimels) en een hoge worteldichtheid (zie paragraaf 2.4.1 voor beschrijving van de methode). De laag 6-30 cm was sterk verdicht, met een lage worteldichtheid, geen zichtbare actieve bodemorganismen, en een zeer gering aantal macroporiën. Beneden $10 \mathrm{~cm}$ diepte was de bodem geoxideerd, wat wijst op een hoge grondwaterstand in de winter. Zavelgrond is van nature gevoelig voor verslemping, wat resulteert in een slechte natuurlijke drainage en plassen water op het land na langer durende regenval. Deze gevoeligheid werd op dit perceel versterkt door een laag gehalte organische stof, vooral veroorzaakt door drie jaar intensieve akkerbouw voordat in 2012 opnieuw gras werd ingezaaid. Een belangrijke bijdrage aan de ontstane bodemverdichting werd verder geleverd door de drijfmestbemesting in februari/maart met een driewieler. De botanische samenstelling van de graszode op dit perceel werd aan het begin van het onderzoek gedomineerd door Engels raaigras (Lolium perenne L.). In voorgaande jaren was het gras gemaaid voor inkuilen (vijf sneden per jaar).

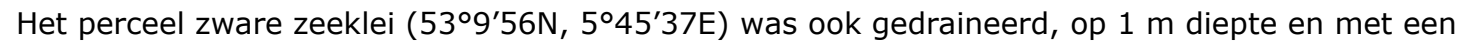
drainafstand van $10 \mathrm{~m}$. Bodemeigenschappen van de laag 0-30 cm waren (in droge grond): lutum $43 \%$, silt 35\%, zand 9\%, pH-KCl 7,1, organische stof $109 \mathrm{~g} \mathrm{~kg}^{-1}$, C-totaal $56 \mathrm{~g} \mathrm{~kg}^{-1}, \mathrm{~N}$-totaal 6,03 g $\mathrm{kg}^{-1}, \mathrm{P}-\mathrm{Al}$ 0,28 $\mathrm{g} \mathrm{P}_{2} \mathrm{O}_{5} \mathrm{~kg}^{-1}, \mathrm{~K}\left(0,01 \mathrm{M} \mathrm{CaCl}_{2}\right)$ 0,081 $\mathrm{g} \mathrm{kg}^{-1}$ en S $\left(0,01 \mathrm{M} \mathrm{CaCl}_{2}\right)$ 0,022 $\mathrm{g} \mathrm{kg}^{-1}$. Hoewel de kleigrond een groter watervasthoudend vermogen had dan de zavelgrond, was de capillaire opstijging een stuk minder. Hierdoor was de kleigrond droogtegevoeliger dan de zavelgrond. Een visuele beoordeling van de bodemstructuur en beworteling, kort voor de start van het onderzoek, liet zien dat de laag 0-10 cm een goede bodemstructuur had, met een hoge dichtheid van wortels en regenwormen (o.a. Lumbricus terrestris en Aporrectodea caliginosa). De laag 10-30 cm was naar beneden in toenemende mate verdicht, met een sterk gereduceerde worteldichtheid, geen zichtbare actieve wormen en een beperkt aantal macroporiën. Beneden $30 \mathrm{~cm}$ diepte waren oude wormgangen aanwezig en was de bodemstructuur beter vergeleken met de laag erboven. De graszode was bij start van het onderzoek minstens 20 jaar oud en de soortsamenstelling werd gedomineerd door Engels raaigras ( $72 \%$ ) en ruwbeemdgras (Poa trivialis L.) (24\%). In voorgaande jaren was het gras alleen gemaaid voor zomerstalvoedering, waarbij spoor-aan-spoor gereden werd, met de opraapwagen achter de trekker. Deze manier van oogsten (en berijden), ook bij natte bodem, heeft waarschijnlijk in belangrijke mate bijgedragen aan de geconstateerde verdichting van dit perceel.

\subsection{Proefopzet}

Het onderzoek werd uitgevoerd om de effecten te meten van een éénmalige woelbehandeling op de bodemstructuur, beworteling en productiviteit van verdicht blijvend grasland tijdens minimaal twee groeiseizoenen. De woelbehandeling werd uitgevoerd in de herfst van 2015 en de effecten werden gemeten in de groeiseizoenen van 2016, 2017, en 2018 (alleen $1^{\text {e }}$ snede). De proefopzet was op beide locaties een gerandomiseerde blokkenproef. De twee behandelingen (controle, woelen) werden op beide locaties vijf keer herhaald, op vijf veldjes $(10 \times 2,7 \mathrm{~m})$ in vijf gerandomiseerde blokken, resulterend in 10 veldjes per locatie en 20 veldjes in totaal. De woelbehandeling werd uitgevoerd op 6 
oktober 2015, na de laatste oogst van dat groeiseizoen. Het woelen werd uitgevoerd met een McConnel Shakeaerator, met vier woelpoten op $60 \mathrm{~cm}$ onderlinge afstand en bevestigd aan de woelpoten 24-cm brede, geharde beitels (McConnel, Ludlow, UK). Met deze machine werd de bovenste laag van $30 \mathrm{~cm}$ (graszode en bodem) in zijn geheel opgetild tot een hoogte van $10-15 \mathrm{~cm}$ en daarna weer neergelaten. De machine was daarnaast voorzien van een door de aftakas aangedreven vibratieunit, waardoor de woelpoten en beitels trilden wanneer ze door de bodem werden getrokken. Met deze trilling wordt beoogd om de weerstand in de grond en het brandstofverbruik en de vermogensbehoefte van de trekker te verminderen. De woeler werd door de bodem getrokken door een relatief zware trekker met een vermogen van 200 pk; het eerdere gebruik van een lichtere trekker met 145 pk op een testlocatie gaf wielslip en aanzienlijke schade aan de graszode.

Het bodemvochtgehalte op het moment van woelen werd, aan de hand van de bodemconditie, geschat op $75-85 \%$ van de veldcapaciteit, en de cumulatieve regenval binnen tien dagen na woelen was hoger dan de cumulatieve evapotranspiratie (KNMI, Bilthoven). Hiermee waren de condities tijdens en na het woelen ideaal (cf. Burgess et al. 2000). Na het woelen werden de veldjes alleen nog bereden door de Haldrup proefveldoogstmachine (wielafstand 0,9 m; gewicht $2030 \mathrm{~kg}$ ), die over de lengte van ieder veldje in het midden reed (zes keer in 2016, vijf keer in 2017, en één keer in 2018).

\subsection{Bemesting}

Het grasland werd per volledig groeiseizoen vier tot vijf keer bemest met kunstmest ( $N$, P en K) en vijf tot zes keer gemaaid. Op de zavelgrond was de $\mathrm{N}$-bemesting voor de eerste vijf sneden in 2016 respectievelijk 120, 90, 70, 50 en $40 \mathrm{~kg} \mathrm{~N} \mathrm{ha}^{-1}$, in 2017 respectievelijk 120, 90, 85, 50 en $40 \mathrm{~kg} \mathrm{~N} \mathrm{ha-}$ 1 , en voor de $1^{\mathrm{e}}$ snede in 2018 was de gift $120 \mathrm{~kg} \mathrm{~N} \mathrm{ha}{ }^{-1}$. Op de zware kleigrond was de N-bemesting voor de eerste vier sneden in 2016 respectievelijk 85, 60, 40, $30 \mathrm{~kg} \mathrm{~N} \mathrm{ha-1}$, voor de eerste vijf sneden in 2017 respectievelijk 95, 70, 50, 40, en $30 \mathrm{~kg} \mathrm{~N} \mathrm{ha}^{-1}$, en voor de $1^{\mathrm{e}}$ snede in 2018 was de gift $95 \mathrm{~kg}$ $\mathrm{N}$ ha-1. Het jaarlijkse niveau van $\mathrm{N}$-bemesting en de verdeling over de sneden was gebaseerd op het geschatte niveau van jaarlijkse $\mathrm{N}$-mineralisatie uit bodemorganische $\mathrm{N}$ (Anonymus 2016). Op de zavelgrond werd in 2017 de N-bemesting voor de derde groeiperiode verhoogd van 70 tot $85 \mathrm{~kg} \mathrm{~N} \mathrm{ha-}$ 1 , gebaseerd op de achterblijvende groeirespons in 2016. Op de zware zeeklei werd in 2017 het niveau van $\mathrm{N}$-bemesting verhoogd, omdat uit de $\mathrm{N}$-opname van het gras bleek dat het niveau van $\mathrm{N}$ mineralisatie in het voorgaande groeiseizoen veel lager was dan geschat. Kunstmest werd toegediend als zwavelzure ammoniak (ZA, 21\% N, 24\% S), kalkammonsalpeter (KAS) met zwavel (24\% N, 6\% S) of standaard KAS $(27 \% \mathrm{~N})$. In 2017 en 2018 werd een deel van de $\mathrm{N}$-gift van voor de eerste snede toegediend als vroege startgift in de vorm van ZA, $15 \mathrm{~kg} \mathrm{~N} \mathrm{ha}^{-1}$ in 2016 en $40 \mathrm{~kg} \mathrm{~N} \mathrm{ha}^{-1}$ in 2018. KAS met zwavel werd alleen toegediend voor de eerste snede; daarna werd alle $\mathrm{N}$-kunstmest toegediend als standaard KAS.

Naast bemesting met $\mathrm{N}$ werden de eerste vijf sneden ook per snede bemest met $9 \mathrm{~kg} \mathrm{P} \mathrm{ha}^{-1}$ in de

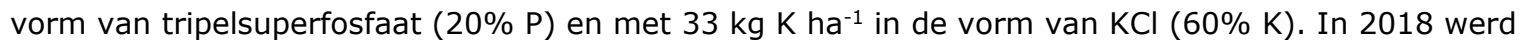
alleen de eerste snede bemest met $\mathrm{P}$ en $\mathrm{K}$. Alle kunstmest werd met de hand gestrooid door een getrainde medewerker van proefbedrijf Dairy Campus. De bemesting voor de eerste snede werd in 2016 toegediend op 11 april, in 2017 op 6 maart (ZA) en 10 april (KAS), en in 2018 op 5 maart (ZA) en 9 april (KAS). Voor iedere volgende snede werd de kunstmest direct na de oogst van de vorige snede gestrooid.

\subsection{Waarnemingen}

\subsubsection{Bodem}

De waarnemingen aan de bodem bestonden uit het meten van de indringingsweerstand, wortelbiomassa, een visuele beoordeling van bodemstructuur, beworteling en wormactiviteit, waterdrainagesnelheid, bulkdichtheid en bodemvruchtbaarheidskenmerken (OS, C en N). De indringingsweerstand werd gemeten 7, 13, 18, 25 en 30 maanden na het woelen (mei en november 2016, maart en november 2017, maart 2018) met een penetrologger (conusoppervlakte 1 
$\mathrm{cm}^{2}$, apexhoek $60^{\circ}$; Eijkelkamp, Giesbeek) met een interval van $1 \mathrm{~cm}$, tot een diepte van $80 \mathrm{~cm}$, op 10 willekeurig gekozen plekken op ieder veldje, tenminste 0,5 m binnen de veldjesgrenzen. Bij de metingen in november en maart was de bodemvochtigheid dicht bij de veldcapaciteit, waardoor de condities voor het meten van indringingsweerstand optimaal waren (cf. Smith et al. 1997). In mei 2016 (na 7 maanden) was de grond te droog voor betrouwbare metingen en in november 2017 (na 25 maanden) werd een methodologische fout gemaakt tijdens het meten van de kleigrond. De resultaten van deze twee metingen zijn daarom niet gerapporteerd (resultaten van de zavelgrond in november 2017 zijn wel gerapporteerd).

De wortelbiomassa werd alleen op de zavelgrond bemonsterd, 7, 13, 19, en 25 maanden na het woelen (mei en november 2016 en 2017). Per veldje werden met een wortelboor (Eijkelkamp, Giesbeek) drie bodemkolommen (82 mm diameter) verzameld van vier bodemlagen (0-10, 10-20, 2030 en $30-40 \mathrm{~cm}$ diepte), tenminste $0,5 \mathrm{~m}$ binnen de veldjesgrenzen. Deze kolommen werden per bodemlaag per veldje samengevoegd en daarna met water gespoeld over een 2-mm zeef. Organische vervuilingen (niet-wortelmateriaal) werden handmatig verwijderd. Daarna werden de monsters 24 uur gedroogd in een oven $\left(70^{\circ} \mathrm{C}\right)$ voor de bepaling van het droge wortelgewicht en berekening van de wortelbiomassa per hectare.

De visuele beoordeling van bodemstructuur, beworteling en wormactiviteit vond plaats 7, 13, 19, en 25 maanden na het woelen (mei en november 2016 en 2017). De beoordeling werd uitgevoerd door een expert, op blokken van $20 \times 25 \mathrm{~cm}$ afkomstig uit de bodemlaag 0-25 cm. De blokken (1 per veldje, steeds op een andere plek) werden uitgegraven met een schop en in zowel de horizontale als verticale richting opengebroken. De bodemstructuur werd beoordeeld door het schatten van het aandeel (\%) kruimels, afgeronde hoekige elementen en scherpe elementen in de blokken. De beworteling werd beoordeeld door het (relatief) scoren van zichtbare worteldichtheid (score 1 - 10; 1 voor geen wortels en 10 voor bovengemiddeld veel wortels) en door het schatten van het aandeel (\%) jonge wortels in het totaal aan wortels. De wormactiviteit werd beoordeeld door het (relatief) scoren van het aantal zichtbare wormgangen (score 1 - 10; 1 voor geen wormgangen en 10 voor bovengemiddeld veel gangen).

De snelheid van waterdrainage werd gemeten in het vroege voorjaar van 2017, alleen op het perceel zavelgrond. Ten behoeve van deze meting werden de opengebleven cilindervormige boorgaten van de wortelbemonstering in november 2016 gebruikt. Deze gaten liepen vol met water tijdens een periode van regenval en draineerden langzaam leeg na het stoppen van de regen. Op basis van deze waarneming tijdens een veldbezoek op 2 februari 2017 ontstond het idee dat verschillen in de afname van de waterhoogte in de boorgaten gebruikt konden worden als een indicatie van de snelheid van waterdrainage. De metingen hiervoor startten op 26 februari 2017, toen de boorgaten tot de rand waren gevuld met water, en werden herhaald na 6, 9, 12, 14, 16, en 18 dagen. Bij iedere meting werd per boorgat de diepte en het waterniveau onder maaiveld gemeten, en werden daarna de resultaten per veldje gemiddeld. Op de gewoelde veldjes werden de metingen beëindigd op 14 maart, omdat sommige boorgaten droog begonnen te vallen, en op de controleveldjes werden de metingen beëindigd op 16 maart.

De bulkdichtheid werd 30 maanden na het woelen (maart 2018) gemeten tot een diepte van $30 \mathrm{~cm}$, in drie lagen van $5 \mathrm{~cm}$ per veldje: de laag $5-10 \mathrm{~cm}, 15-20 \mathrm{~cm}$ en $25-30 \mathrm{~cm}$. Van ieder veldje werden per laag twee intacte ringmonsters met $100 \mathrm{~cm}^{3}$ grond genomen, op twee plekken en tenminste 0,5 m binnen de veldjesgrenzen. De ringen werden gewogen, 24 uur gedroogd bij $70^{\circ} \mathrm{C}$, teruggewogen, en de resultaten werden gemiddeld per $5-\mathrm{cm}$ laag per veldje.

De bodemvruchtbaarheidskenmerken werden eveneens 30 maanden na het woelen gemeten (maart 2018). Van ieder veldje werd de grond bemonsterd tot $30 \mathrm{~cm}$ diepte, in drie lagen van $10 \mathrm{~cm}$, op 10 plekken regelmatig verdeeld over het veldje en tenminste 0,5 $\mathrm{m}$ binnen de veldjesgrenzen. De monsters werden per veldje per $10-\mathrm{cm}$ bodemlaag samengevoegd, gewogen en 24 uur gedroogd bij $70^{\circ} \mathrm{C}$. Na het drogen werden de monsters verstuurd naar Eurofins Agro (Wageningen) voor bepaling van het gehalte organische stof (gloeiverlies) en het totale gehalte $\mathrm{C}$ en $\mathrm{N}$ (element analyzer). Met behulp van de gemeten gehalten werden ook de bodemvoorraden organische stof (OS), C-totaal en $\mathrm{N}$-totaal berekend. Het doel van deze berekening was om verschillen in gehalten tussen de 
behandelingen te kunnen vertalen naar hoeveelheden op hectareniveau, en verschillen in N-voorraad te kunnen relateren aan verschillen in $\mathrm{N}$-opname van het gras tijdens de proefperiode. Voor de controleveldjes werden de bodemvoorraden per $10-\mathrm{cm}$ bodemlaag berekend door per laag de gehalten te vermenigvuldigen met de bulkdichtheid, waarbij de bulkdichtheid van de 5 -cm lagen als representatief voor de $10-\mathrm{cm}$ lagen werd gebruikt (omdat de bulkdichtheid in de grond kan toenemen met de diepte, kan dit een lichte overschatting geven). Voor de berekening van de bodemvoorraden van de gewoelde veldjes werd eveneens de bulkdichtheid van de controleveldjes gebruikt. De bulkdichtheden van de gewoelde veldjes zelf zijn voor dat doel minder bruikbaar, omdat deze door woelen kunnen afnemen. Hierdoor zou bij vergelijking van de resultaten van beide behandelingen niet dezelfde hoeveelheid grond vergeleken worden. Daarnaast wordt door het gebruik van verschillende bulkdichtheden een extra variatiebron in de berekeningen geïntroduceerd, wat een betrouwbare vergelijking lastig maakt.

\subsubsection{Gewas}

De gewasmetingen bestonden uit meting van de bovengrondse opbrengst, bovengrondse N-opname, en de botanische samenstelling van de graszode. De opbrengst werd bepaald door het gras te maaien met een proefveldoogstmachine (J. Haldrup a/s, Løgstør, Denemarken), op een hoogte van $6 \mathrm{~cm}$ en over een breedte van $1,5 \mathrm{~m}$ in het midden van ieder veldje (totale gemaaide oppervlakte $15 \mathrm{~m}^{2}$ ). De veldjes werden in 2016 gemaaid op 9 mei, 10 juni, 22 juli, 25 augustus, 29 september en 1 november (laatste oogst alleen op het perceel zavel); in 2017 op 9 mei, 12 juni, 17 juli, 22 augustus en 26 september, en in 2018 op 8 mei. Het geoogste gras werd gewogen en bemonsterd en de monsters werden 48 uur gedroogd bij $70^{\circ} \mathrm{C}$ om het drooggewicht te bepalen en de drogestofopbrengst en $\mathrm{N}$ opname te berekenen. Het $\mathrm{N}$-gehalte in de gedroogde monsters werd door Eurofins Agro bepaald met een element analyzer (NEN 16634-1, 2008).

De botanische samenstelling van de graszode werd visueel geschat om te bepalen of woelen leidde tot een meer open zode, een lagere relatieve bedekking met Engels raaigras, en een hogere relatieve bedekking met ongewenste soorten. De beoordeling werd uitgevoerd 8, 11, 20 en 25 maanden na behandeling (mei en september 2016, mei en oktober 2017) door een expert en bestond uit het schatten van de totale relatieve bodembedekking (\%) door de graszode en het aandeel (\%) van iedere aangetroffen soort daarin.

\section{$2.5 \quad$ Statistische analyse}

De resultaten werden per locatie en per tijdstip statistisch geanalyseerd door variantieanalyse met het statistische pakket Genstat ( $18^{\mathrm{e}}$ editie). De indringingsweerstand werd geanalyseerd per $10-\mathrm{cm}$ bodemlaag, waarbij de 10 metingen (per 1-cm toename in diepte) werden gemiddeld. De wortelmassa werd geanalyseerd per $10 \mathrm{~cm}$ bodemlaag en in totaal (laag 0-40 cm). Het waterniveau in de boorgaten werd per tijdstip geanalyseerd. De bulkdichtheid werd geanalyseerd per 5-cm bodemlaag. De gehalten OS, C-totaal en $\mathrm{N}$-totaal werden geanalyseerd per $10-\mathrm{cm}$ bodemlaag. Verschillen in gehalten OS, $\mathrm{C}$ en $\mathrm{N}$ tussen het begin en einde van de proefperiode op de controleveldjes konden niet statistisch geanalyseerd worden, omdat de gehalten aan het begin van de meetperiode niet per veldje waren gemeten, maar als verzamelmonster van het hele proefveld. De grasopbrengst en $\mathrm{N}$-opname werden geanalyseerd per individuele snede en voor alle sneden opgeteld per groeiseizoen. De botanische samenstelling werd geanalyseerd per tijdstip. 


\section{Resultaten}

\section{$3.1 \quad$ Bodem}

\subsubsection{Indringingsweerstand}

Op beide grondsoorten was de indringingsweerstand voor tenminste 30 maanden (laatste meting) lager op de gewoelde veldjes vergeleken met de controleveldjes (Figuur 1). Op de zavelgrond neigde de weerstand in de laag 0-10 cm ernaar significant lager te zijn na 7 maanden, was deze significant lager na 13 en 18 maanden, was er geen verschil na 25 maanden, en neigde de weerstand ernaar lager te zijn na 30 maanden (resp. $P=0,09, P<0,001, P=0,005, P=0,52$ en $P=0,06$ ). De weerstand in de lagen $10-20 \mathrm{~cm}$ en $20-30 \mathrm{~cm}$ was op de gewoelde veldjes significant lager op alle meetdatums $(P<0,002)$. Na 25 maanden werd er op de gewoelde veldjes voor de eerste keer een significant lagere weerstand gemeten in de laag 70-80 cm $(P=0,02)$, en na 30 maanden een significant lagere weerstand in zowel de laag 70-80 cm $(P=0,04)$ als in de laag $60-70 \mathrm{~cm}(P=0,05)$. Daarnaast neigde na 30 maanden ook de indringingsweerstand in de laag 30-40 ernaar lager te zijn na woelen $(P=0,08)$, ook hier voor de eerste keer. De woelbehandeling kreeg daarmee in de loop van de meetperiode effect op meer en diepere bodemlagen, tot ver onder de woeldiepte (Figuur 1).
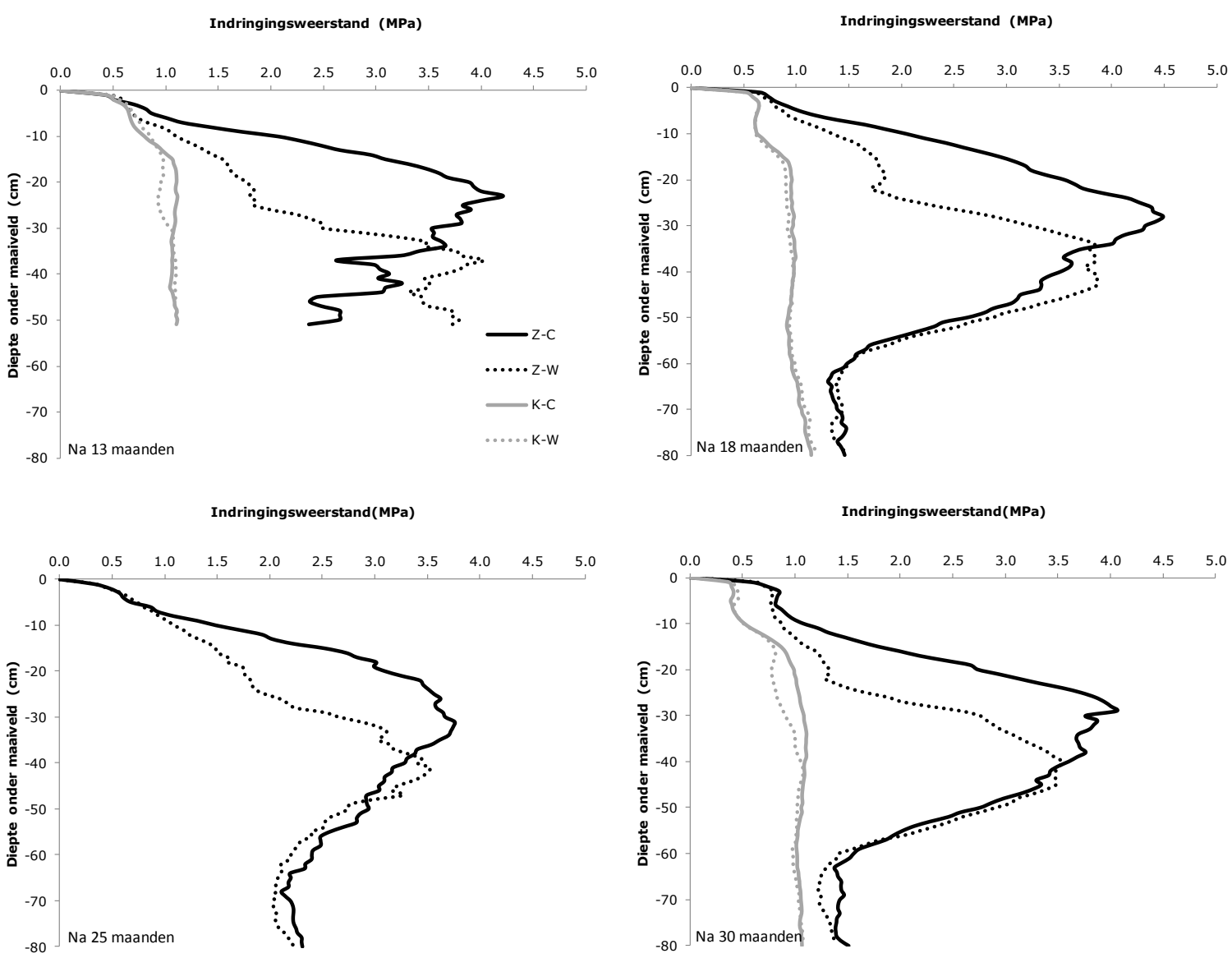

Figuur 1 Indringingsweerstand (MPa) in de bodemlaag 0-80 cm van grasland op een perceel verdichte zavelgrond $(Z)$ en zware kleigrond $(K)$, zoals beïnvloed door woelen $(W)$ en vergeleken met de onbehandelde controle (C). Metingen werden uitgevoerd 11, 18, 25 en 30 maanden na woelen begin oktober 2015. De resultaten van de zware klei bij de meting na 25 maanden zijn niet weergegeven vanwege een fout uitgevoerde meting 
Op de zware kleigrond was de indringingsweerstand van de gewoelde veldjes bij de meting na 13 maanden significant lager $(P=0,01)$ in de laag $10-30 \mathrm{~cm}$ en bij de metingen daarna significant lager $(P<0,05)$ in de laag 10-40 cm, vergeleken met de controleveldjes (Figuur 1 ).

\subsubsection{Wortelmassa}

Op de zavelgrond was na 7 maanden (mei 2016) de wortelmassa van de gewoelde veldjes significant hoger in de bodemlagen $0-10 \mathrm{~cm}$ en $20-30 \mathrm{~cm}$ (resp. $\mathrm{P}=0,05$ en $\mathrm{P}=0,01$ ) en ook de totale wortelmassa was hoger $(P=0,03$ ) (Figuur 2). Na 13 maanden (november 2016) neigde de wortelmassa in laag 0-10 cm ernaar significant lager te zijn $(P=0,08)$, in plaats van hoger, en was de totale wortelmassa lager $(P=0,04)$. Na 19 maanden (mei 2017) was de wortelmassa in bodemlaag 10-20 cm lager $(P=0,04)$ en neigde de totale wortelmassa ernaar lager te zijn $(P=0,08)$. Na 25 maanden (november 2017) waren er geen significante verschillen (meer) tussen de gewoelde veldjes en controleveldjes, per $10-\mathrm{cm}$ laag of in totaal $(P>0,10)$. Op de zware kleigrond was de wortelmassa niet gemeten.

Op de zavelgrond verdubbelde de totale wortelmassa tijdens de 18 maanden durende meetperiode. De totale wortelmassa van de controleveldjes nam toe van 5,5 ton DS ha-1 in mei 2016 (eerste meting) tot 11,6 ton DS ha-1 in november 2017 (laatste meting) (Figuur 2).
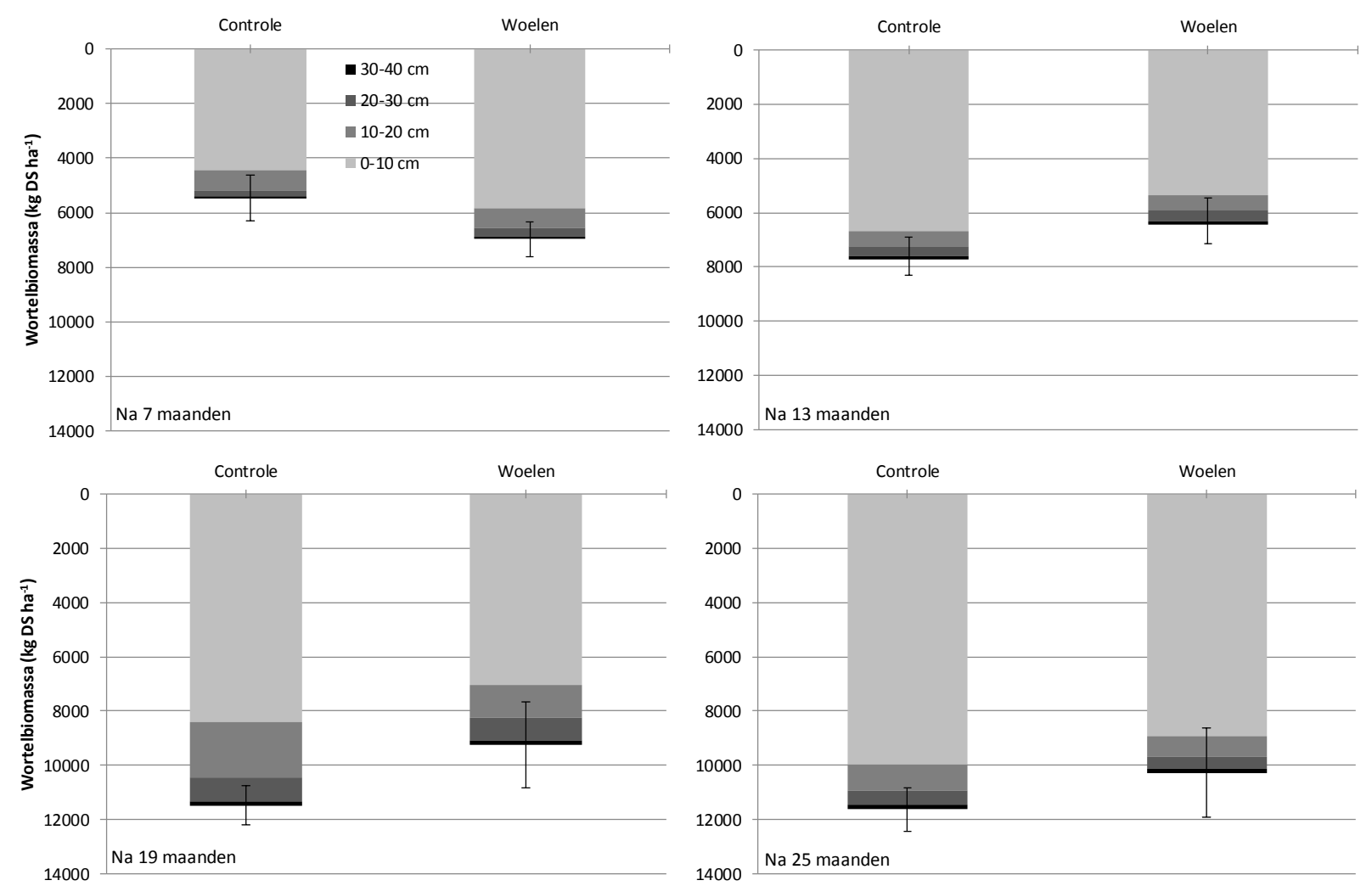

Figuur 2 Wortelmassa in bodemlagen 0-10, 10-20, 20-30 en 30-40 cm van grasland op een verdichte zavelgrond, zoals beïnvloed door woelen en vergeleken met de onbehandelde controle. Metingen werden uitgevoerd 7, 13, 19, en 25 maanden na woelen begin oktober 2015. De foutenbalken vertegenwoordigen $2 x$ de standaardfout van de totale wortelmassa (laag 0-40 cm)

\subsubsection{Bodemstructuur, worteldichtheid en wormgangen}

Op de zavelgrond had woelen 25 maanden lang (tot de laatste meting) een positief effect op de bodemstructuur in de laag 0-25 cm, alhoewel de effecten wat varieerden tussen de meettijdstippen. Het aandeel kruimels was na 7 maanden hoger, na 13 maanden onveranderd, na 19 maanden hoger, en neigde na 25 maanden ernaar hoger te zijn (resp. $P=0,01, P=0,19, P<0,001$ en $P=0,05$ ). Het aandeel kruimels was toen resp. $14 \%$ en $28 \%$, gem. $18 \%, 11 \%$ en $22 \%$, en $15 \%$ en $22 \%$, op de 
controleveldjes en gewoelde veldjes. Het aandeel scherpblokkige elementen was na 7 maanden lager, neigde na 13 maanden ernaar lager te zijn, was na 19 maanden lager, en was na 25 maanden onveranderd $(P=0,01, P=0,09, P<0,001$ en $P=0,28)$. Het aandeel scherpblokkige elementen was toen resp. $64 \%$ en $37 \%$, $44 \%$ en $23 \%$, $75 \%$ en $30 \%$, en gem. $39 \%$. De score voor totale worteldichtheid in de laag 0-25 cm was hoger na 7 maanden, onveranderd na 13 maanden, hoger na 19 maanden, en neigde ernaar hoger te zijn na 25 maanden (resp. $P=0,01, P=0,62, P<0,001$ en $P$ $=0,10)$. De scores waren toen resp. 5,8 en 7,6, gem. 6,7,5,7 en 7,9, en 6,4 en 7,2, voor de controleveldjes en gewoelde veldjes. Het aandeel jonge wortels in de laag 0-25 cm was hoger na 7 maanden, onveranderd na 13 maanden, hoger na 19 maanden, en neigde ernaar hoger te zijn na 25 maanden (resp. $\mathrm{P}=0,04, \mathrm{P}=0,20, \mathrm{P}=0,001$ en $\mathrm{P}=0,06$ ). Het aandeel was toen resp. $44 \%$ en $53 \%$, gem. $44 \%$, $35 \%$ en $60 \%$, en $20 \%$ en $37 \%$, voor de controleveldjes en gewoelde veldjes. De score voor wormgangen was onveranderd na 7 maanden, neigde ernaar hoger te zijn na 13 maanden, en was hoger na 19 en 25 maanden (resp. $P=0,37, P=0,09, P<0,001$ en $P=0,006$ ). De score was toen resp. gemiddeld $1,1,1,2$ en $3,2,3,0$ en 7,2 , en 2,2 en 6,8 , voor de controleveldjes en gewoelde veldjes.

Op de zware klei had woelen 19 maanden lang een positief effect op de bodemstructuur in de laag 0$25 \mathrm{~cm}$, maar ook op deze grondsoort varieerden effecten tussen tijdstippen. Het aandeel kruimels was onveranderd na 7 maanden, hoger na 13 maanden, en onveranderd na 19 en 25 maanden (resp. P = $0,30, P=0,03, P=0,14$ en $P=0,35$ ). Het aandeel was toen resp. gemiddeld $15 \%, 17 \%$ en $22 \%$, gem. $19 \%$, en gem. $27 \%$, voor de controleveldjes en gewoelde veldjes. Het aandeel scherpblokkige elementen neigde ernaar lager te zijn na 7 maanden, was lager na 13 maanden, neigde ernaar lager te zijn na 19 maanden, en was onveranderd na 25 maanden (resp. $\mathrm{P}=0,06, \mathrm{P}=0,02, \mathrm{P}=0,08$ en $\mathrm{P}$ $=0,90)$. Het aandeel was toen resp. $52 \%$ en $25 \%, 26 \%$ en $10 \%, 50 \%$ en $21 \%$, en gem. $30 \%$, voor de controleveldjes en gewoelde veldjes. De score voor totale worteldichtheid was hoger na 7 en 13 maanden, maar onveranderd na 19 en 25 maanden (resp. $P=0,03, P=0,02, P=0,26$ en $P=0,75$ ). De score was toen resp. 5,8 en 7,0,5,8 en 6,6, gem. 6,4, en gem. 6,9 voor de controleveldjes en gewoelde veldjes. Het aandeel jonge wortels was op geen enkel meettijdstip beïnvloed door woelen en was na 7, 13, 19 en 25 maanden gemiddeld $51 \%, 10 \%, 55 \%$ en $18 \%$ (resp. $\mathrm{P}=0,18, \mathrm{P}=0,21, \mathrm{P}=$ $0,31$ en $\mathrm{P}=0,65)$. De score voor wormgangen was hoger na 7 maanden, onveranderd na 13 maanden, neigde ernaar hoger te zijn na 19 maanden, en was onveranderd na 25 maanden (resp. $\mathrm{P}<$ $0,001, P=1,00, P=0,06$, en $P=0,70$ ). De score was toen resp. 4,0 en 7,0 , gem. 4,6, 2,6 en 5,6, en gem. 5,7), voor de controleveldjes en gewoelde veldjes.

\subsubsection{Waterdrainagesnelheid}

Het waterniveau in de boorgaten was op de meeste meettijdstippen (behalve 0 en 18 dagen na start van de metingen) significant lager op de gewoelde veldjes vergeleken met de controleveldjes ( $P<$ 0,01 ) (Figuur 3). De waterdrainagesnelheid werd voor beide behandelingen grotendeels gelijk op 4 maart, zes dagen na start van de metingen (Figuur 3). Op dat moment was het waterniveau in de boorgaten respectievelijk 2,4 en 13,7 cm onder het maaiveld voor de controleveldjes en de gewoelde veldjes. De gemiddelde waterdrainagesnelheid in de periode daarna, tussen 4 en 14 maart ( 6 en 16 dagen na start van de metingen), was gemiddeld $1,27 \mathrm{~cm} \mathrm{dag}^{-1}$ op de controleveldjes en $1,38 \mathrm{~cm}^{\text {dag- }}$ ${ }^{1}$ op de gewoelde veldjes. Bij een gemiddelde boorgatdiepte van $29,4 \mathrm{~cm}$ begonnen de boorgaten in de gewoelde veldjes daardoor 17 dagen na start van de metingen op te drogen en liepen daarmee gemiddeld 10 dagen voor op de boorgaten van de controleveldjes 


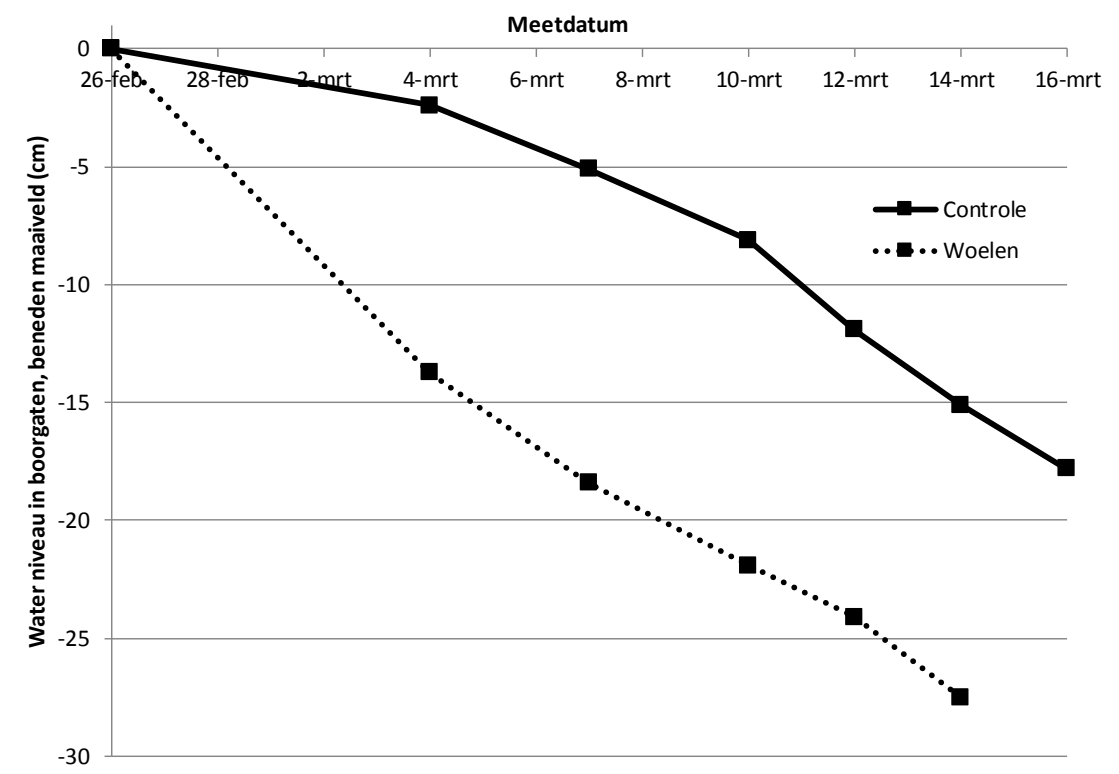

Figuur 3 Afname van het waterniveau in boorgaten in gewoelde veldjes en controleveldjes op grasland op een verdichte zavelgrond

\subsubsection{Bulkdichtheid en bodemvruchtbaarheid}

Op de zavelgrond was 30 maanden na woelen de bulkdichtheid in de laag 5-10 cm van de gewoelde veldjes niet significant verschillend van de controleveldjes $(P=0,16)$ en was gemiddeld $1,43 \mathrm{~g} \mathrm{~cm}^{-3}$. De bulkdichtheid in de bodemlagen $15-20 \mathrm{~cm}$ en $25-30 \mathrm{~cm}$ was significant lager voor de gewoelde veldjes vergeleken met de controleveldjes (resp. $\mathrm{P}=0,01$ en $\mathrm{P}=0,02$ ) en was respectievelijk 1,53 en $1,58 \mathrm{~g} \mathrm{~cm}^{-3}$ in de laag $15-20 \mathrm{~cm}$ en 1,49 en $1,57 \mathrm{~g} \mathrm{~cm}^{-3}$ in de laag $25-30 \mathrm{~cm}$. Op de zware kleigrond was 30 maanden na woelen de bulkdichtheid in de bodemlagen $5-10 \mathrm{~cm}, 15-20 \mathrm{~cm}$ en $25-30 \mathrm{~cm}$ onveranderd voor de gewoelde veldjes vergeleken met de controleveldjes (resp. $P=0,83, P=0,17$ en $\mathrm{P}=0,45$ ). De bulkdichtheid was gemiddeld respectievelijk $0,74 \mathrm{~g} \mathrm{~cm}^{-3}, 1,09 \mathrm{~g} \mathrm{~cm}^{-3}$, en $1,12 \mathrm{~g} \mathrm{~cm}^{-3}$ in de lagen $5-10 \mathrm{~cm}, 15-20 \mathrm{~cm}$ en $25-30 \mathrm{~cm}$.

Op de zavelgrond waren er 30 maanden na woelen geen significante verschillen, of een neiging tot significante verschillen, in OS-, C- of $\mathrm{N}$-gehalte tussen de controleveldjes en de gewoelde veldjes ( $\mathrm{P}>$ 0,10 ) (Tabel 1 ). Wel was het OS-gehalte bij de gewoelde veldjes in alle drie bodemlagen steeds $3 \%$ lager; het $\mathrm{N}$-gehalte was alleen in laag $0-10 \mathrm{~cm} 3 \%$ lager en in de andere twee bodemlagen gelijk.

Tabel 1 Gehalte OS (\%), C-totaal (\%) en $\mathrm{N}$-totaal $\left(\mathrm{mg} \mathrm{kg}^{-1}\right)$ in de bodem van verdicht grasland op een perceel zavel- of zware kleigrond, gemeten 2,5 jaar na het uitvoeren van een woelbehandeling, in drie bodemlagen $(\mathrm{cm})$.

\begin{tabular}{|c|c|c|c|c|c|c|c|c|c|c|}
\hline Grond & Laag & \multicolumn{3}{|c|}{ os } & \multicolumn{3}{|c|}{ C-totaal } & \multicolumn{3}{|c|}{ N-totaal } \\
\hline \multirow[t]{3}{*}{ Zavel } & $0-10$ & 3,46 & 3,34 & 0,57 & 1,52 & 1,50 & 0,83 & 1464 & 1416 & 0,50 \\
\hline & $10-20$ & 2,42 & 2,34 & 0,24 & 0,92 & 0,90 & 0,62 & 1014 & 1014 & 1,00 \\
\hline & $20-30$ & 2,18 & 2,12 & 0,47 & 0,74 & 0,78 & 0,37 & 886 & 888 & 0,95 \\
\hline Klei & $20-30$ & 8,1 & 8,3 & 0,59 & 3,32 & 3,22 & 0,56 & 3238 & 3270 & 0,94 \\
\hline
\end{tabular}

1) $P<0,05$ geeft een significant verschil aan, per bodemparameter binnen een bodemlaag

Op de zware kleigrond was het OS-gehalte in de laag 0-10 cm lager op de gewoelde veldjes vergeleken met de controleveldjes $(P=0,01)$. In deze laag waren er geen significante verschillen in $\mathrm{C}$ - of $\mathrm{N}$-gehalte (resp. $\mathrm{P}=0,12$ en $\mathrm{P}=0,11$ ). In de laag $10-20 \mathrm{~cm}$ waren de gehalten OS, $\mathrm{C}$ en $\mathrm{N}$ 
significant lager in de gewoelde veldjes vergeleken met de controleveldjes $(P \leq 0,01)$. In de laag $20-$ $30 \mathrm{~cm}$ waren er geen significante verschillen, of een neiging tot significante verschillen, in gehalte OS, $\mathrm{C}$ en $\mathrm{N}$ tussen de gewoelde veldjes en controleveldjes $(P>0,10)$. De berekende bodemvoorraden OS, $\mathrm{C}$ en $\mathrm{N}$ op de controleveldjes zijn gegeven in Tabel 2.

Tabel 2 Voorraden OS (ton ha-1), C-totaal (ton ha-1) en $\mathrm{N}$-totaal ( $\mathrm{kg} \mathrm{ha}^{-1}$ ) in de bodem van controleveldjes op verdicht grasland op een perceel zavel- of zware kleigrond, 2,5 jaar na het uitvoeren van een woelbehandeling, in drie bodemlagen $(\mathrm{cm})$ en in het totaal.

\begin{tabular}{cccccccc} 
Grond & Laag & \multicolumn{2}{c}{ OS-voorraad } & \multicolumn{2}{c}{ C-voorraad } & \multicolumn{2}{c}{ N-voorraad } \\
& & Controle & Woelen & Controle & Woelen & Controle & Woelen \\
\hline \multirow{2}{*}{ Zavel } & $0-10$ & 50 & 49 & 22 & 22 & 2125 & 2055 \\
\hline & $10-20$ & 38 & 37 & 15 & 14 & 1602 & 1602 \\
\hline \multirow{2}{*}{ Klei } & $20-30$ & 34 & 33 & 12 & 12 & 1388 & 1391 \\
\hline & Totaal & 123 & 119 & 48 & 48 & 5114 & 5048 \\
\hline & $0-10$ & 128 & 122 & 58 & 55 & 5955 & 5733 \\
\hline & $10-20$ & 142 & 132 & 61 & 57 & 6480 & 6048 \\
\hline & $20-30$ & 92 & 94 & 38 & 37 & 3687 & 3723 \\
\hline
\end{tabular}

\subsection{Gras}

\subsubsection{Opbrengst}

Op de zavelgrond was op de gewoelde veldjes de opbrengst van de eerste snede in alle drie groeiseizoenen hoger vergeleken met de controleveldjes (Tabel 3). Dit verschil was significant $(P<$ $0,05)$ in de eerste twee groeiseizoenen, maar niet in het derde groeiseizoen. De opbrengst van latere sneden werd door woelen niet beïnvloed $(P>0,10)$. De jaaropbrengst van het eerste groeiseizoen neigde ernaar hoger te zijn op de gewoelde veldjes $(P=0,10)$, maar de jaaropbrengst van het tweede groeiseizoen werd niet significant beïnvloed $(P>0,10)$.

Tabel 3 Opbrengst ( $k g \mathrm{DS} \mathrm{ha}^{-1}$ ) van grasland op een verdichte zavel- of zware kleigrond, per snede en per jaar, zoals beïnvloed door woelen in het najaar van 2015.

\begin{tabular}{|c|c|c|c|c|c|c|c|}
\hline \multirow{3}{*}{ Jaar } & \multirow{3}{*}{ Snede \# } & \multicolumn{3}{|l|}{ Zavel } & \multicolumn{3}{|l|}{ Zware klei } \\
\hline & & Behandeling & & P-waarde ${ }^{1)}$ & Behandeling & & P-waarde \\
\hline & & Controle & Woelen & & Controle & Woelen & \\
\hline \multirow[t]{7}{*}{2016} & 1 & 3665 & 4205 & $<0,001$ & 4013 & 4266 & 0,05 \\
\hline & 2 & 4730 & 4762 & 0,85 & 4227 & 3932 & 0,07 \\
\hline & 3 & 4020 & 4276 & 0,46 & 3323 & 3451 & 0,33 \\
\hline & 4 & 2306 & 2308 & 0,98 & 1940 & 1771 & 0,01 \\
\hline & 5 & 2250 & 2330 & 0,22 & 1125 & 974 & 0,01 \\
\hline & 6 & $426^{2)}$ & 439 & 0,07 & $-3)$ & - & - \\
\hline & Totaal & 17397 & 18320 & 0,10 & 14628 & 14394 & 0,32 \\
\hline \multirow[t]{6}{*}{2017} & 1 & 3810 & 4181 & 0,01 & 4070 & 3792 & 0,09 \\
\hline & 2 & 4560 & 4446 & 0,11 & 3515 & 3079 & 0,03 \\
\hline & 3 & 3488 & 3388 & 0,47 & 2815 & 2583 & 0,09 \\
\hline & 4 & 3626 & 3599 & 0,79 & 2673 & 2537 & 0,41 \\
\hline & 5 & 2064 & 2048 & 0,66 & 1746 & 1538 & 0,25 \\
\hline & Totaal & 17548 & 17662 & 0,72 & 14819 & 13529 & 0,02 \\
\hline 2018 & 1 & 2981 & 3435 & 0,25 & 4298 & 3895 & 0,03 \\
\hline
\end{tabular}

1) $P<0,05$ geeft een significant verschil aan, binnen een regel en een grondsoort; ${ }^{2)}$ opbrengst schoonmaaien; ${ }^{3)}$ niet geoogst vanwege ontbreken oogstbare opbrengst 
Op de zware kleigrond had woelen een significant positief effect $(P=0,05)$ op de opbrengst van de eerste snede van het eerste groeiseizoen, maar de opbrengst van de tweede snede neigde ernaar significant lager te zijn $(P=0,07)$ en de opbrengst van de vierde en vijfde snede was significant lager (resp. $P=0,01$ en $P=0,01$ ) (Tabel 3 ). De jaaropbrengst van het eerste groeiseizoen werd echter niet significant negatief beïnvloed $(P>0,10)$. In het tweede groeiseizoen gaf woelen een lagere opbrengst van de tweede snede $(P=0,03)$ en neigde de opbrengst van de eerste en derde snede ernaar lager te zijn (resp. $P=0,09$ en $P=0,09$ ). De jaaropbrengst van het tweede groeiseizoen was significant lager op de gewoelde veldjes vergeleken met de controleveldjes $(P=0,02)$. In het derde groeiseizoen was de opbrengst van de eerste snede significant lager als gevolg van woelen $(P=0,03)($ Tabel 3$)$.

\subsubsection{Stikstofopname}

Op de zavelgrond gaf woelen een hogere $\mathrm{N}$-opname van de eerste snede in alle drie groeiseizoenen, vergeleken met de controle (Tabel 4). Dit effect was significant in de eerste twee groeiseizoenen $(P<$ $0,05)$. In het eerste groeiseizoen gaf woelen ook een hogere $\mathrm{N}$-opname van de derde en vijfde snede, en op jaarbasis $(P<0,05)$. In het tweede groeiseizoen werd de $\mathrm{N}$-opname na de eerste snede niet significant beïnvloed door woelen en was er ook geen effect op jaarbasis $(P>0,10)$.

Tabel 4 Stikstofopname ( $\mathrm{kg} \mathrm{N} \mathrm{ha}^{-1}$ ) van grasland op een verdichte zavel- of zware kleigrond, per snede en per jaar, zoals beïnvloed door woelen in het najaar van 2015.

\begin{tabular}{|c|c|c|c|c|c|c|c|}
\hline & & Zavel & & & Zware klei & & \\
\hline Jaar & Snede \# & Behandeling & & P-waarde ${ }^{1)}$ & Behandeling & & P-waarde \\
\hline & & Controle & Woelen & & Controle & Woelen & \\
\hline \multirow[t]{6}{*}{2016} & 1 & 99 & 120 & 0,01 & 117 & 131 & 0,05 \\
\hline & 2 & 120 & 126 & 0,51 & 96 & 95 & 0,81 \\
\hline & 3 & 89 & 96 & 0,04 & 83 & 77 & 0,32 \\
\hline & 5 & 58 & 61 & 0,02 & 32 & 28 & 0,02 \\
\hline & 6 & 14 & 14 & 0,16 & & & \\
\hline & Totaal & 438 & 478 & 0,04 & 381 & 382 & 0,96 \\
\hline \multirow{4}{*}{2017} & 3 & 100 & 100 & 0,90 & 72 & 71 & 0,22 \\
\hline & 4 & 89 & 90 & 0,79 & 85 & 82 & 0,38 \\
\hline & 5 & 46 & 49 & 0,14 & 54 & 52 & 0,52 \\
\hline & Totaal & 466 & 490 & 0,21 & 419 & 397 & 0,10 \\
\hline 2018 & 1 & 93 & 105 & 0,26 & 143 & 121 & 0,04 \\
\hline
\end{tabular}

1) $P<0,05$ geeft een significant verschil aan, binnen een regel en grondsoort; ${ }^{2)}$ niet geoogst vanwege ontbreken oogstbare opbrengst

Op de zware kleigrond gaf woelen een significant hogere $\mathrm{N}$-opname van de eerste snede in het eerste groeiseizoen $(P<0,05)$, maar een lagere $N$-opname van de vijfde snede in dat seizoen $(P<0,05)$ (Tabel 4). De N-opname van andere sneden werd niet significant beïnvloed door woelen, behalve die van de eerste snede van het derde groeiseizoen, waar de $\mathrm{N}$-opname van gewoelde veldjes lager was vergeleken met de controleveldjes $(P=0,04)$. De cumulatieve $\mathrm{N}$-opname werd in beide groeiseizoenen niet beïnvloed door woelen $(P>0,10)$ (Tabel 4$)$.

\subsubsection{Botanische samenstelling}

Op de zavelgrond had woelen alleen effect op de totale bedekking van de grond door de graszode. De bedekking was niet verschillend na 8 maanden, maar was na 11, 20 en 25 maanden lager op de gewoelde veldjes vergeleken met de controleveldjes (resp. $P=1,00, P=0,02, P=0,02$ en $P=0,02$ ). De bedekking was toen resp. gemiddeld $95 \%, 97 \%$ en $95 \%, 97 \%$ en $95 \%$, en $98 \%$ en $96 \%$. Het relatieve aandeel van de aanwezige soorten, L. perenne L. (95\%), Phleum pratense L. (2\%), Poa 
trivialis L. (3\%), en Poa annua L. (1\%), werd niet beïnvloed door woelen (resp. P =0,32, P = 0,18, P $=0,37$ en $\mathrm{P}=1,00$ ) (gerapporteerde aandelen en $\mathrm{P}$-waarden bij meting na 25 maanden).

Op de zware kleigrond had woelen zowel een significant effect op de totale bedekking als ook op het relatieve aandeel van twee grassoorten in de zode. De totale bedekking was niet verschillend na 8 maanden, maar was na 11, 20 en 25 maanden lager op de gewoelde veldjes vergeleken met de controleveldjes (resp. $\mathrm{P}=1,00, \mathrm{P}=0,004, \mathrm{P}=0,004$, en $\mathrm{P}=0,05$ ). De bedekking was toen resp. gemiddeld $98 \%$, $96 \%$ en $93 \%, 96 \%$ en $93 \%$, en $96 \%$ en $94 \%$. Het relatieve aandeel van $L$. perenne was niet verschillend na 8 maanden, maar neigde ernaar lager te zijn na 11 maanden en was na 20 en 25 maanden lager op de gewoelde veldjes vergeleken met de controleveldjes (resp. $\mathrm{P}=0,14, \mathrm{P}=$ $0,06, P=0,02$ en $\mathrm{P}=0,04)$. Het relatieve aandeel was toen resp. gemiddeld $72 \%, 76 \%$ en $74 \%, 79 \%$ en $77 \%$, en 79 en $78 \%$. Het relatieve aandeel van Poa trivialis neigde ernaar hoger te zijn na 8 maanden, was onveranderd na 11 maanden, neigde ernaar hoger te zijn na 20 maanden, en was hoger na 25 maanden (resp. $\mathrm{P} 0,08, \mathrm{P}=0,18, \mathrm{P}=0,09$ en $\mathrm{P}=0,003$ ). Het relatieve aandeel was toen resp. $23 \%$ en $24 \%$, gem. $19 \%, 16 \%$ en $17 \%$, en $16 \%$ en $18 \%$. Het relatieve aandeel van de andere aanwezige soorten, Poa annua L. (1\%) en Elymus repens L. (1\%), was onveranderd (resp. P = 0,62 en $\mathrm{P}=1,00)$ (gerapporteerde aandelen en $\mathrm{P}$-waarden bij meting na 25 maanden). 


\section{Discussie}

\subsection{Zavelgrond}

Woelen gaf op het perceel zavelgrond een duidelijke verbetering van de bodemstructuur, zowel gemeten aan de indringingsweerstand als door visuele boordeling. De verbeteringen hielden aan tot de laatste waarneming, 30 maanden na het uitvoeren van de woelbehandeling. Als gevolg van de minder dichte bodemstructuur kon regenwater sneller draineren; in het voorjaar van 2017 liep daardoor de waterdrainage op de veldjes met woelbehandeling 10 dagen voor op de controleveldjes. Door deze voorsprong drogen de veldjes met woelbehandeling ook eerder op, waardoor het luchtgehalte in de bodem eerder toeneemt en de wortelgroei en grasgroei eerder kunnen starten.

De verbeteringen in de bodemstructuur leidden op de zavelgrond tot een zichtbaar betere beworteling, met een hogere worteldichtheid en een hoger aandeel jonge wortels (behalve bij de meting 13 maanden na woelen). De wortelmassa was echter alleen hoger bij de meting 13 maanden na het woelen; bij de latere metingen was de wortelmassa van de gewoelde veldjes lager (alhoewel niet altijd significant). Deze (schijnbare) tegenstrijdigheid in resultaten kan verklaard worden door een snellere afbraak van dode wortels als gevolg van woelen. Bij de bemonstering op wortelmassa worden zowel levende als dode wortels meegenomen. Door woelen komt er meer lucht in de grond, waardoor de activiteit van micro-organismen en bodemfauna kan toenemen. Als gevolg daarvan kan jonge OS, zoals aanwezig in dode wortels, versneld worden afgebroken, waardoor deze op een later meettijdstip niet meer aanwezig is in de gemeten wortelmassa. De totale wortelmassa kan hierdoor lager zijn na woelen, zelfs bij een toename van het aandeel jonge wortels. Hierbij speelt ook een rol dat jonge wortels nog weinig verhout zijn en daardoor relatief weinig bijdragen aan de wortelmassa, uitgedrukt in drogestof. In het huidige onderzoek werd een verhoogde activiteit van bodemfauna bevestigd door de hogere score voor wormgangen na woelen. Een verhoogde afbraak van oS lijkt bevestigd te worden door een wat lager OS-gehalte aan het einde van de proefperiode in de gewoelde veldjes vergeleken met de controleveldjes (hoewel deze verschillen niet significant waren, $\mathrm{P}>0,05$ ).

De verbeteringen in bodemstructuur, waterdrainage, beworteling, en wormactiviteit, leidden niet tot een duidelijk hoger niveau van grasopbrengst en $\mathrm{N}$-opname na woelen. Wel waren grasopbrengst en $\mathrm{N}$-opname van de eerste snede in alle drie groeiseizoenen hoger. Dit lijkt het directe gevolg te zijn van het positieve effect van woelen op de waterdrainage vroeg in het groeiseizoen, en daarmee op het luchtgehalte, de wortelgroei en grasgroei. Het verschil in $\mathrm{N}$-opname was relatief groot in de eerste snede van het eerste groeiseizoen, waarschijnlijk mede als gevolg van een tijdelijk verhoogde $\mathrm{N}$ mineralisatie direct na woelen (De Boer et al. 2018).

Een hoger luchtgehalte kan leiden tot een verhoogde $\mathrm{N}$-mineralisatie en een hogere $\mathrm{N}$-opname door het gras. De hogere $\mathrm{N}$-opname in de eerste snede kan echter maar voor een klein deel hierdoor verklaard worden, omdat de gemiddelde $\mathrm{N}$-mineralisatie in het vroege voorjaar relatief laag is. Daarnaast was ook het jaarniveau van mineralisatie op deze zavelgrond laag; de berekende NLV was $70 \mathrm{~kg} \mathrm{~N} \mathrm{ha}^{-1}$ jaar $^{-1}$ bij start van de proef (laag 0-10 cm; Anonymus 2016). In onderzoek van Verloop et al. (2014) was de dagelijkse $\mathrm{N}$-mineralisatie van blijvend grasland, op droogtegevoelige zandgrond, in de maand maart gemiddeld $0,8 \mathrm{~kg} \mathrm{~N} \mathrm{ha}^{-1} \mathrm{dag}^{-1}$, ofwel $0,2 \%$ van de gemiddelde jaarlijkse $\mathrm{NLV}$. Bij dit percentage zou er op de zavelgrond $1,4 \mathrm{~kg} \mathrm{~N}$ gemineraliseerd zijn tijdens een periode van 10 dagen in maart, bij een NLV van 70. Daarnaast is op zavelgrond de N-mineralisatiesnelheid meestal lager dan op zandgrond. Het is daarmee onwaarschijnlijk dat het 10 dagen eerder opdrogen van de gewoelde veldjes in de eerste helft van maart 2017 geleid heeft tot een verschil in N-opname van 14 $\mathrm{kg} \mathrm{N} \mathrm{ha}^{-1}$ jaar in de eerste snede van dat jaar (Tabel 4).

Een andere deelverklaring voor de hogere $\mathrm{N}$-opname in de eerste snede is dat het $\mathrm{N}$-verlies door denitrificatie van de met KAS toegediende nitraat lager is geweest op de (drogere) gewoelde veldjes, vergeleken met de controleveldjes. Dit effect kan echter nauwelijks een rol gespeeld hebben, omdat 
op het tijdstip van toediening van de KAS (9-11 april) in de drie jaren alle veldjes al grotendeels waren opgedroogd. Daarnaast kwam tijdens de vierde snede van het tweede groeiseizoen (2017) het proefveld als gevolg van regenval tijdelijk onder water te staan, maar er was geen verschil in $\mathrm{N}$ opname tussen gewoelde en controleveldjes (Tabel 4). Bij een lager niveau van denitrificatie zou er op de gewoelde veldjes echter een hogere $\mathrm{N}$-opname verwacht worden.

Het grootste deel van de hogere $\mathrm{N}$-opname in de eerste snede van de gewoelde veldjes kan verklaard worden door een hogere benutting van de met kunstmest toegediende $\mathrm{N}$, als gevolg van een verbeterde beworteling. Hoewel de totale wortelmassa (levende + dode wortels) van de gewoelde veldjes gedurende een groot deel van de proefperiode lager was dan van de controleveldjes, was de worteldichtheid, en het aandeel jonge wortels daarin, meestal hoger. Samenvattend kan daarom geconcludeerd worden dat de hogere $\mathrm{N}$-opname op de gewoelde veldjes grotendeels werd veroorzaakt door een betere benutting van toegediende $\mathrm{N}$, vooral in het voorjaar.

Behalve een hogere $\mathrm{N}$-opname in de eerste snede was in het eerste groeiseizoen de $\mathrm{N}$-opname van de derde en vijfde snede ook significant hoger (Tabel 4). In het tweede groeiseizoen leken de $\mathrm{N}$-opname van de tweede en vijfde snede ook wat hoger te zijn, maar de verschillen waren klein en niet significant. In het onderzoek van de Boer et al. (2018) leidde een wat hogere N-opname op korte termijn na woelen tot een wat lagere $\mathrm{N}$-opname op de langere termijn, waarschijnlijk als gevolg van een afname van de voorraad snel mineraliseerbare organische $\mathrm{N}$ in de bodem. In het huidige onderzoek werd dit effect niet gemeten, ondanks dat door het lage niveau van NLV verwacht zou worden dat dit effect eerder zou optreden en groter zou zijn. Het ontbreken van dit effect is een verdere bevestiging dat de hogere $\mathrm{N}$-opname na woelen eerder het gevolg was van een betere benutting van gegeven $\mathrm{N}$ dan van een verhoogd niveau van $\mathrm{N}$-mineralisatie.

Naast de wat hogere $\mathrm{N}$-opname door het gras leidde het woelen van de zavelgrond ook tot een licht verlies van bodemvruchtbaarheid, gemeten aan het OS- en $\mathrm{N}$-gehalte. Het $\mathrm{N}$-gehalte in de laag 0-10 $\mathrm{cm}$ was aan het einde van de proefperiode $3 \%$ lager op de gewoelde veldjes vergeleken met de controleveldjes, hoewel dit verschil niet significant was. Vergeleken met de $\mathrm{N}$-voorraad in de laag 0-30 $\mathrm{cm}$ van de controleveldjes (Tabel 2) was de $\mathrm{N}$-voorraad op de gewoelde veldjes $66 \mathrm{~kg} \mathrm{~N} \mathrm{ha}^{-1}$ lager. Aangenomen dat dit een werkelijk verschil was (de afname is niet significant, maar wel logisch), is dit verlies waarschijnlijk vooral opgetreden kort na het uitvoeren van de woelbehandeling, begin oktober 2015. Grondbewerking door woelen kan de N-mineralisatie stimuleren, wat leidt tot het beschikbaar komen van extra minerale, plantopneembare N. Tijdens een veldbezoek in november 2015, een maand na woelen, bleek het gras op de gewoelde veldjes donkerder van kleur te zijn dan op de controleveldjes, een bevestiging dat er op de gewoelde veldjes extra $\mathrm{N}$-opname had plaatsgevonden. Het is waarschijnlijk dat er maar een deel van de extra gemineraliseerde $\mathrm{N}$ werd opgenomen; een ander deel kan tijdens de winter en het vroege voorjaar van 2016 zijn uitgespoeld naar het grond- en oppervlaktewater of gedenitrificeerd. Aangenomen dat er inderdaad sprake was van een $\mathrm{N}$-verlies uit de bodemvoorraad als gevolg van woelen, dan werd dit op de zavelgrond gecompenseerd door de hogere $\mathrm{N}$-opname van het gras over de proefperiode $\left(76 \mathrm{~kg} \mathrm{~N} \mathrm{ha}^{-1}\right)$.

Een inschatting van de praktische meerwaarde van woelen kan gegeven worden door de directe kosten en opbrengsten over de proefperiode op financiële waarde te zetten. Hierbij wordt aan $\mathrm{N}$ een waarde toegekend van $€ 1,0 \mathrm{~kg}^{-1}$ en aan grasopbrengst een waarde van $€ 0,187 \mathrm{~kg} \mathrm{DS}^{-1}$ (Blanken et al. 2017). Bij eenmalige woelkosten van $€ 80 \mathrm{ha}^{-1}$ en kosten voor een (aangenomen) $\mathrm{N}$-verlies uit de bodemvoorraad van $€ 66 \mathrm{ha}^{-1}$, waren de totale kosten $€ 146 \mathrm{ha}^{-1}$. De opbrengsten bestonden uit $€ 279$ $\mathrm{ha}^{-1}$ voor de extra grasopbrengst ( $1491 \mathrm{~kg} \mathrm{DS} \mathrm{ha}^{-1}$ ) en $€ 76 \mathrm{ha}^{-1}$ voor extra $\mathrm{N}$-opname, voor een totale opbrengst van $€ 355$. Hiermee was het netto financiële voordeel over de hele proefperiode $€$ $209 \mathrm{ha}^{-1}$. Geconstateerd kan worden dat het woelen van de bouwvoor van deze sterk verdichte zavelgrond uit agronomisch oogpunt een aantal voordelen bood en (daardoor) financieel licht positief uitpakte. 


\subsection{Zware kleigrond}

Woelen gaf ook op het (minder verdichte) perceel zware kleigrond een verbetering van de bodemstructuur, zowel gemeten aan de indringingsweerstand als door visuele beoordeling. Wel waren de effecten kleiner dan op de zavelgrond en duurden ze korter. De verbetering in bodemstructuur leidde op de zware kleigrond ook tot een zichtbaar betere beworteling, maar dit effect kwam alleen tot uitdrukking in de totale worteldichtheid, niet in het aandeel jonge wortels, en het verdween in de periode tussen 13 en 19 maanden na woelen. Omdat de wortelmassa niet gemeten was, kon er geen vergelijking gemaakt worden tussen de hogere wortelscores en eventuele verschillen in wortelmassa. Woelen gaf op de zware kleigrond een duidelijk hogere afbraak van organische stof, resulterend in significant lagere gehalten OS in bodemlagen $0-10 \mathrm{~cm}$ en $10-20 \mathrm{~cm}$ aan het einde van de proefperiode.

Op de zware kleigrond leidden de verbeteringen in de bodemstructuur, beworteling, en wormactiviteit, niet tot een verbetering van de grasopbrengst en $\mathrm{N}$-opname, maar tot een verslechtering. Na een eenmalig positief effect in de eerste snede van 2016 (eerste snede na uitvoeren woelbehandeling) was de grasopbrengst in de volgende sneden regelmatig lager op de gewoelde veldjes vergeleken met de controleveldjes. Bij de laatste gemeten snede van de proefperiode, de eerste snede van 2018, waren zowel de grasopbrengst als $\mathrm{N}$-opname van de gewoelde veldjes significant lager. De neiging tot een lagere grasopbrengst en $\mathrm{N}$-opname na woelen kan deels het gevolg geweest zijn van de relatief grote achteruitgang in bodemvruchtbaarheid op deze zware kleigrond. Op de gewoelde veldjes was de $\mathrm{N}$ voorraad in de laag $0-30 \mathrm{~cm}$ aan het einde van de proefperiode $618 \mathrm{~kg} \mathrm{~N} \mathrm{ha}^{-1}$ lager vergeleken met de controleveldjes (Tabel 3). Van deze hoeveelheid was $432 \mathrm{~kg} \mathrm{~N} \mathrm{ha}^{-1}$ het resultaat van een significant verschil in $\mathrm{N}$-gehalte in bodemlaag $10-20 \mathrm{~cm}$. Het grootste deel van dit $\mathrm{N}$-verlies is waarschijnlijk vooral opgetreden kort na het uitvoeren van de woelbehandeling, overeenkomstig de situatie op de zavelgrond. Dit betekent waarschijnlijk ook dat in de winter en het voorjaar van 2016 een deel van deze $\mathrm{N}$ als nitraat is uitgespoeld en gedenitrificeerd. Waar op het perceel zavelgrond een mogelijk $\mathrm{N}$ verlies uit de bodem als gevolg van woelen werd gecompenseerd door een licht hogere N-opname, werd op de zware kleigrond het $\mathrm{N}$-verlies uit de bodem nog wat versterkt door een iets lagere $\mathrm{N}$ opname van het gras over de proefperiode $\left(43 \mathrm{~kg} \mathrm{~N} \mathrm{ha}^{-1}\right)$. Hierdoor was het totale $\mathrm{N}$-verlies aan het einde van de proefperiode toegenomen van $618 \mathrm{~kg} \mathrm{~N} \mathrm{ha}^{-1}$ (bodem) tot $661 \mathrm{~kg} \mathrm{~N} \mathrm{ha}^{-1}$ (bodem + gras).

Naast een mogelijk negatief effect van woelen op de snel mineraliseerbare bodemvoorraad $\mathrm{N}$ (De Boer et al. 2018), en daarmee op de N-opname en grasopbrengst op langere termijn, kan een ander effect ook een belangrijke bijdrage hebben geleverd. Na de droge maand augustus in 2016 bleken er tijdens een veldbezoek in september aanzienlijk meer en grotere droogtescheuren aanwezig te zijn op de gewoelde veldjes vergeleken met de controleveldjes. Deze waarnemingen wekten de indruk dat als gevolg van woelen de macro-bodemstructuur blijvend was verstoord. Dit kan gevolgen hebben gehad voor de wateraanvoer via capillaire opstijging van grondwater, waardoor de gewoelde veldjes gevoeliger waren voor droogteschade dan de controleveldjes. In de herfst en winter van 2016 werd het proefveld aangetast door veldmuizen, waarvan de gangen en vraatsporen vooral aangetroffen werden in de gewoelde veldjes. De indruk was dat door de lossere bodemstructuur en de aanwezige scheuren en gaten deze veldjes aantrekkelijker waren voor de muizen. In de herfst en winter van 2017 breidde de muizenaantasting zich uit naar de controleveldjes, zodat in het voorjaar van 2018 vrijwel alle veldjes waren aangetast. Opvallend was dat de muizenschade op de (gewoelde) proefveldjes in eerste instantie groter was dan op het omringende perceel; dit was vooral tijdens de winter van 2016 goed zichtbaar.

Op de zware kleigrond was de in oktober van 2015 aanwezige verdichting in het voorjaar van 2016 grotendeels verdwenen. Hieruit werd geconcludeerd dat deze zware kleigrond, als gevolg van zwel en krimp, maar ook vanwege hoge wormactiviteit, in staat was om de aanwezige verdichting op natuurlijke wijze op te heffen en zichzelf te 'repareren'. Woelen had een averechts effect, waardoor de controleveldjes in betere conditie waren dan de gewoelde veldjes. Op dit type zware kleigrond is woelen daarom af te raden en kan beter vertrouwd worden op het natuurlijke herstellend vermogen. Bij het op financiële waarde zetten van directe kosten en opbrengsten over de proefperiode, met geschatte eenmalige woelkosten van $€ 100$ ha $^{-1}$ (op zware klei is meer trekkracht nodig dan op zavel, waardoor dieselverbruik en kosten hoger zijn), waren de totale kosten over de proefperiode minstens 
$€ 718 \mathrm{ha}^{-1}$. Door de lagere grasopbrengst (1927 kg DS ha-1) en $\mathrm{N}$-opname was er geen sprake van extra opbrengsten, maar van extra kosten van in totaal $€ 403 \mathrm{ha}^{-1}$. Hiermee was er sprake van een financieel nadeel van $€ 1121$ ha $^{-1}$ over de hele proefperiode. Omdat op dit bodemtype er overwegend sprake was van negatieve effecten, moet geconstateerd worden dat het woelen van deze zware kleigrond uit agronomisch en economisch oogpunt sterk af te raden was. 


\section{Conclusies}

- Woelen van grasland op het perceel verdichte zavelgrond gaf over de hele proefperiode $(2,5$ jaar) een aanhoudende duidelijke verbetering van de bodemstructuur, beworteling en wormactiviteit. Op het perceel zware kleigrond waren de effecten beperkter en korter van duur

- $\quad$ Op de zavelgrond (zware klei niet gemeten) liep in het voorjaar van 2017 de waterdrainage op de gewoelde veldjes 10 dagen voor op de controleveldjes

- De verbeteringen in bodemstructuur, beworteling, wormactiviteit en waterdrainage (zavelgrond) leidden niet tot een structureel hoger niveau van grasopbrengst en $\mathrm{N}$-opname:

- Op de zavelgrond was de grasopbrengst door woelen hoger in de eerste snede van alle drie groeiseizoenen, maar verschilde deze weinig in de volgende sneden. Over de hele proefperiode $(2,5$ jaar) was de opbrengst $4 \%$ hoger (1491 kg DS ha-1);

- Op de zware kleigrond was de grasopbrengst alleen in de eerste snede van het eerste groeiseizoen hoger, en was deze in de sneden daarna regelmatig lager. Over de hele proefperiode was de opbrengst $6 \%$ lager $\left(1927 \mathrm{~kg} \mathrm{DS} \mathrm{ha}^{-1}\right)$;

- Op de zavelgrond was de $\mathrm{N}$-opname in de eerste snede van alle drie groeiseizoenen 13$22 \%$ hoger na woelen (12-22 $\left.\mathrm{kg} \mathrm{N} \mathrm{ha}^{-1}\right)$. In het eerste groeiseizoen na woelen was ook de N-opname van de derde en vijfde snede, en van het hele seizoen, hoger. Over de hele proefperiode was de $\mathrm{N}$-opname $8 \%$ hoger $\left(76 \mathrm{~kg} \mathrm{~N} \mathrm{ha}^{-1}\right)$;

- Op de zware kleigrond was de $\mathrm{N}$-opname alleen in de eerste snede na woelen hoger, en daarna regelmatig lager. Over de hele proefperiode was de $\mathrm{N}$-opname $4 \%$ lager (43 kg N $\left.\mathrm{ha}^{-1}\right)$.

- Woelen gaf op beide bodemtypen een verlies van bodemvruchtbaarheid, gemeten aan de gehalten OS, C-totaal en $\mathrm{N}$-totaal in de bouwvoor $(0-30 \mathrm{~cm})$. Op de zavel- en zware kleigrond was aan het einde van de proefperiode de $\mathrm{N}$-voorraad van de gewoelde veldjes resp. 66 en 618 $\mathrm{kg} \mathrm{N} \mathrm{ha-1} \mathrm{lager} \mathrm{vergeleken} \mathrm{met} \mathrm{de} \mathrm{controleveldjes} \mathrm{(bij} \mathrm{de} \mathrm{zavel} \mathrm{was} \mathrm{dit} \mathrm{verschil} \mathrm{niet} \mathrm{significant)}$

- Woelen gaf een (geringe) verslechtering van de graszodekwaliteit, door een licht lagere totale zodebedekking (beide locaties), een lager relatief aandeel van L. perenne (zware klei) en een hoger relatief aandeel van $P$. trivialis (zware klei)

- De zware kleigrond bleek, als gevolg van zwel en krimp, maar ook vanwege hoge wormactiviteit, in staat om de aanwezige verdichting op natuurlijke wijze op te heffen. Woelen had een averechts effect, waardoor de controleveldjes in betere conditie waren dan de gewoelde veldjes. Op dit type zware kleigrond is woelen daarom af te raden

- Wanneer de gemeten kosten en opbrengsten van woelen op directe financiële waarde worden gezet, dan resteerde over de 2,5 jaar durende proefperiode een nettowinst van $€ 209 \mathrm{ha}^{-1}$ op de zavelgrond en een nettoverlies van $€ 1121 \mathrm{ha}^{-1}$ op de zware kleigrond. Woelen was daarmee financieel licht interessant op de zavelgrond en sterk af te raden op de zware kleigrond

- $\quad$ Bij de beslissing om verdicht grasland wel of niet te woelen is dus maatwerk nodig, waarbij de mate van verdichting en de natuurlijke herstelcapaciteit van de grond een belangrijke rol spelen. 


\section{Dankwoord}

Wij danken melkveehouders Jan-Jetzes Bakker (perceel zavelgrond) en Andries-Jan de Boer (perceel zware kleigrond) voor het ter beschikking stellen van de proefpercelen; Dairy Campus voor de algehele proefuitvoering; Pool Agri voor het ter beschikking stellen van een McConnel Shakeaerator, inclusief transport en personele ondersteuning; Pedro Janssen, Stijn van de Goor, Riekje Bruinenberg en Hans Dullaert voor de bepaling van de indringingsweerstand, wortelmassa en bulkdichtheid; Coen ter Berg voor de visuele beoordeling van de bodemstructuur, beworteling en wormgangen; en Henk Schilder voor de botanische kartering.

Het onderzoek in dit rapport werd gefinancierd door ZuivelNL (www.zuivelnl.org), het Samenwerkingsverband Noord-Nederland (SNN), Ruimtelijk Economisch Programma, en het publiekprivate samenwerkingsverband 'Ruwvoerproductie en Bodemmanagement'. De financiering door SNN werd uitgevoerd via het Innovatiefonds Dairy Campus. Het publiek-private samenwerkingsverband (PPS) 'Ruwvoerproductie en Bodemmanagement' is een samenwerkingsverband van Wageningen Research en het Louis Bolk Instituut met bedrijfslevenpartners Agrifirm, Barenbrug Holland, Bionext, CUMELA Nederland, DLF, DSV Zaden Nederland, Euralis, ForFarmersGroup, J.Joordens, Zaadhandel, Limagrain Nederland, LTO Nederland, MOVO Zaden, NMB, Pioneer, Plantum, Syngenta, Vandinter SEMO en ZuiveINL (www.ruwvoerenbodem.nl), medegefinancierd door het Ministerie van LNV via de topsector Agri \& Food (TKI-AF-15284 en TKI-AF-15102) (BO-31.03-010-001, BO-31.03-008-007). 


\section{Literatuur}

Anonymus, 2016. Adviesbasis Bemesting Grasland en Voedergewassen, Wageningen Livestock Research, Wageningen

Blanken K, de Buisonje F, Evers A, Ouweltjes W, Verkaik J, Vermeij I, Wemmenhove H (2017). KWIN 2017-2018, Handboek 33, Wageningen Livestock Research, Wageningen

De Boer HC, Deru JGC, Van Eekeren N (2018) Sward lifting in compacted grassland: effects on soil structure, grass rooting and productivity. Soil \& Tillage Research 184:317-325.

Burgess CP, Chapman R, Singleton PL, Thom ER (2000) Shallow mechanical loosening of a soil under dairy cattle grazing: effects on soil and pasture. New Zealand Journal of Agricultural Research 43:279-290

Harrison DF, Cameron KC, McLaren RG (1994) Effects of subsoil loosening on soil physical properties, plant root growth, and pasture yield. New Zealand Journal of Agricultural Research 37:559-567

NEN 16634-1 (2008) Food products - Determination of the total nitrogen content by combustion according to the Dumas principle and calculation of the crude protein content - Part 1: Oilseeds and animal feeding stuffs (www.nen.nl), Delft

Smith CW, Johnston MA, Lorentz S (1997) The effect of soil compaction and soil physical properties on the mechanical resistance of South African forestry soils. Geoderma 78:93-111

Verloop J, Hilhorst GJ, Oenema J, van Keulen H, Sebek LBJ, van Ittersum, MK (2014) Soil N mineralization in a dairy production system with grass and forage crops. Nutrient Cycling in Agroecosystems 98:267-280 

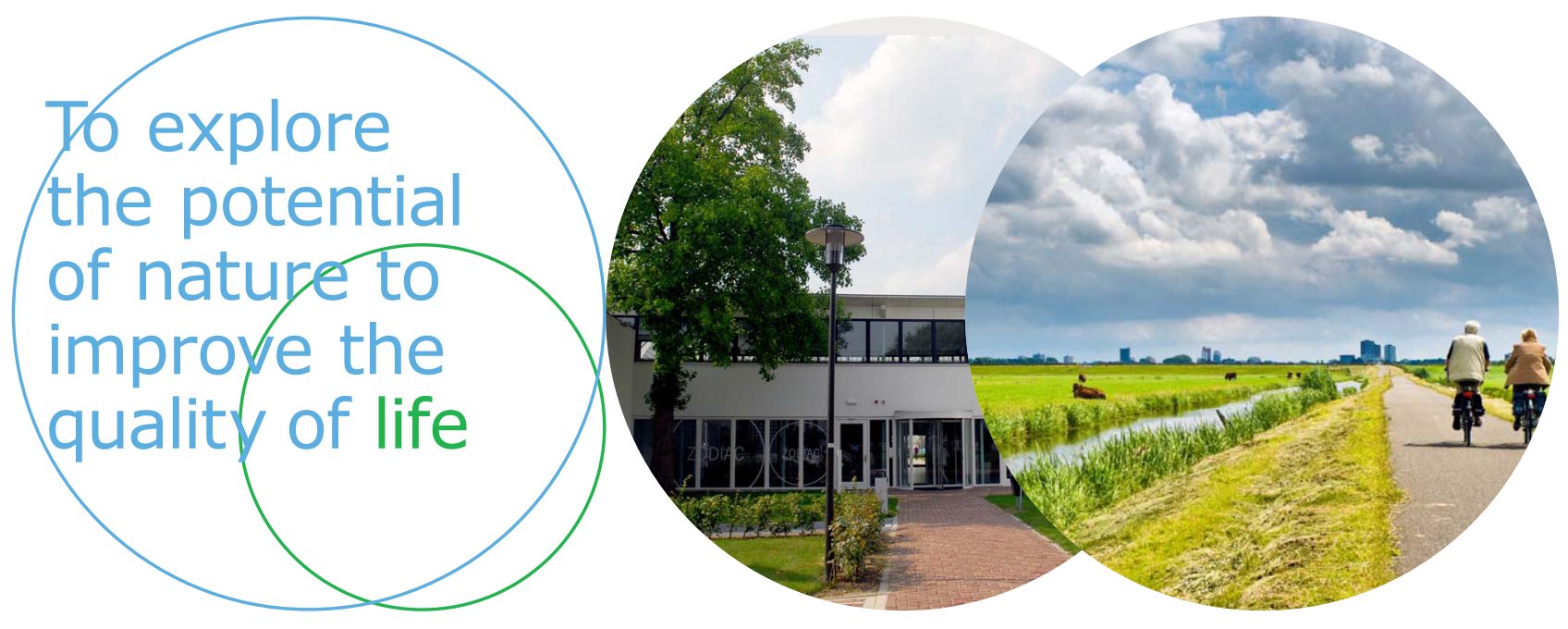

Wageningen Livestock Research Postbus 338

Wageningen Livestock Research ontwikkelt kennis voor een zorgvuldige en $6700 \mathrm{AH}$ Wageningen

T 0317483953

renderende veehouderij, vertaalt deze naar praktijkgerichte oplossingen en innovaties, en zorgt voor doorstroming van deze kennis. Onze wetenschappelijke E info.livestockresearch@wur.nl www.wur.nl/ livestock-research kennis op het gebied van veehouderijsystemen en van voeding, genetica, welzijn en milieu-impact van landbouwhuisdieren integreren we, samen met onze klanten, tot veehouderijconcepten voor de $21 \mathrm{e}$ eeuw.

De missie van Wageningen University \& Research is 'To explore the potential of nature to improve the quality of life'. Binnen Wageningen University \& Research bundelen 9 gespecialiseerde onderzoeksinstituten van Stichting Wageningen Research en Wageningen University hun krachten om bij te dragen aan de oplossing van belangrijke vragen in het domein van gezonde voeding en leefomgeving. Met ongeveer 30 vestigingen, 6.500 medewerkers en 10.000 studenten behoort Wageningen University \& Research wereldwijd tot de aansprekende kennisinstellingen binnen haar domein. De integrale benadering van de vraagstukken en de samenwerking tussen verschillende disciplines vormen het hart van de unieke Wageningen aanpak. 